\section{Kaleki opór}

Robert McRuer

TEKSTY DRUGIE 2020, NR 2, S. 232-271
Źródło: Tekst jest drugim rozdziałem z książki Crip Times: Disability, Globalization, and Resistance, New York University Press, New York 2018.

DOI: $10.18318 /$ td.2020.2.16

G dzie na świecie moglibyśmy umiejscowić kaleki opór?? Jaki kształt mógłby przybrać w czasie polityki oszczędności? Ten rozdział jest poświęcony analizie kalekich taktyk oporu i bada szeroki wybór zbiorowych projektów, które odpowiadają - w krytycznie niepełnosprawny sposób - na globalną politykę oszczędności oraz na skorelowane z nią ograniczenia reprezentacji. Modele kontrreprezentacji lub kontrrozgłosu, proponowane przez interesujące mnie taktyki, były często opisywane przez myślicieli krytycznych - zwłaszcza teoretyków queer - jako „tworzące świat”2. Kevin Floyd, by scharakteryzować „improwizacyjną" naturę tego typu praktyk,

1 Określenie crip resistance użyte w oryginale jest wieloznaczne. Może oznaczać zarówno opór kalek, kaleki opór, jak i grać ze sformułowaniem creep resistance, które można przetłumaczyć jako odporność na odkształcenia (lub wytrzymałość materiałową) [przyp. tłum.].

2 W rzeczywistości "QED: A Journal in GLBTQ Worldmaking”, czasopismo poświęcone studiom kulturowym [do którego tytułu nawiązuje ten termin - przyp. tłum.], rozpoczęło działalność jesienią 2013 roku.

\section{Robert McRuer - \\ amerykański badacz zajmujący się proble- matyką queer oraz niepełnosprawności, autor m.in. książek The Queer Renais- sance: Contemporary American Literature and the Reinvention of Lesbian and Gay Identities (1997); Crip Theory: Cultural Signs of Queerness and Disability (2006) oraz Crip Times: Essays on Disability, Sexuality, and Neoliberalism (2018).}


powołuje się na prace Lauren Berlant i Michaela Warnera ${ }^{3}$, w których idea queerowego

„świata” zmienia się, podobnie jak kategoria tego, co „publiczne”, w zależności od zbiorowości i grupy, ponieważ z konieczności obejmuje więcej osób, niż da się zidentyfikować, więcej przestrzeni niż tylko ta możliwa do zmapowania w relacji do kilku punktów orientacyjnych, a także wiele różnych modeli odczuwania, które są raczej możliwe do nauczenia, niż doświadczane jako przyrodzone prawo. Świat queer jest przestrzenią wejść, wyjść, nieusystematyzowanych linii znajomości, projektowanych horyzontów, typowych przykładów, alternatywnych ścieżek, blokad i niewspółmiernej geografii. ${ }^{4}$

Jak sugerowałem w pierwszym rozdziale książki Crip Times. Disability, Globalization and Resistance ${ }^{5}$, Bethany Stevens zaobserwowała, że projekt „This Is What Disability Looks Like" został potępiony przez część krytyków jako „zbyt queerowy, zbyt prowokacyjny seksualnie, zbyt fantastyczny”. Przesadna seksualizacja i queerowość nie są jednak wyłącznymi powodami, dla których była to akcja „tworząca świat” w rozumieniu Berlant i Warnera. Metafory przestrzenne, których użyli badacze, by zdefiniować queerowy świat (wejścia, wyjścia, projektowane horyzonty, alternatywne ścieżki, blokady, niewspółmierna geografia) niemal dosłownie definiują świat niepełnosprawnych, tak jak „nieusystematyzowane linie znajomości” budują to, co Corbett Joan O’Toole (między innymi) określiłaby jako wcielenie "wewnątrzsterownego systemu wsparcia", pozwalającego niepełnosprawności ciągle materializować się w przestrzeni ${ }^{6}$. Mówiąc inaczej: improwizowane, kalekie tworzenie świata, jak w projektach takich jak „This Is What Disability Looks Like”, wyłania się z codziennego doświadczenia osób niepełnosprawnych - nawigowania i remapowania świata multiplikującego to, co Berlant i Warner określają jako typowe przykłady takiej improwizacji. By zaadaptować lub okaleczyć

3 L. Berlant, M. Warner Sex in Public, "Critical Inquiry" 1998, no. 2, s. 547-566.

4 Cytat za: K. Floyd The Reification of Desire: Toward a Queer Marxism, University of Minnesota Press, Minneapolis 2009, s. 588. [Jeśli nie zaznaczono inaczej, wszystkie fragmenty przekłada tłumacz - przyp. tłum.].

5 R. McRuer Crip Times: Disability, Globalization, and Resistance, New York University Press, New York 2018.

6 J.C. O'Toole Fading Scars: My Queer Disability History, Fort Worth, Autonomous Press 2015, s. 67. 
[crip] koncepcję tworzenia świata, „więcej osób, niż można zidentyfikować”, jest zaangażowana w krytycznie ograniczony [disabled] projekt nawigowania ableizmu, na którym opiera się neoliberalizm, oraz w przekształcanie ableistycznej przestrzeni, konstruowanej przez tenże neoliberalizm. Różnorodny aktywizm omawiany w tym rozdziale generuje ponadto kalekie modele odczuwania, które są raczej uczone i przekazywane niż doświadczane jako wrodzone.

Rozdział ten kontynuuje projekt analizowania kalekiej socjalności ${ }^{7}$ w sposób, który - zgodnie z szerokim rozumieniem tego terminu przez Floyda może być określony jako „pornograficzny”. Pornograficzna socjalność, analizowana przez badacza, konstruuje „świat inherentnie krytycznych praktyk i wiedzy". W jego interpretacji queerowa, pornograficzna socjalność jest radykalna z wielu powodów, nie tylko dlatego że odrzuca „rozróżnienie tego, co seksualne i społeczne"8. Zamierzam rozszerzyć koncepcję Floyda na kategorię kalekiego czasu, by za jej pomocą wyobrazić i opisać n i e p eł n o s p r a w ną socjalność, która w podobny sposób historycznie odrzucała rozróżnienie między tym, co społeczne, a ciałami zaangażowanymi w s pektru m in ty m ny ch praktyk, do których z całą pewnością należy seks (jak wspomnienia O'Toole i wielu innych jasno wskazują) oraz inne ucieleśnione formy bycia niezwyczajnym. By ustrukturyzować tę pornograficzną wyobraźnię, niniejszy tekst zwraca się w stronę różnych aktywizmów, dosłownie - jak by to określili Berlant i Warner - „geograficznie niewspółmiernych”. Te działania, które analizuję w Crip Times obok innych kreatywnych praktyk, są nieuchronnie zaraźliwe, gdyż sytuują cielesność w samym centrum sprzeciwu wobec polityki oszczędności.

Po części wywodu poświęconej wprost kalekiej/queerowej teorii o p o r u (pojęcie to jest kluczowe dla tego tekstu), zajmę się aktywizmem, który będę interpretował jako kaleki, najpierw w Stanach Zjednoczonych, Chile, Hiszpanii i Grecji, potem zaś wrócę do przykładu Wielkiej Brytanii. Pierwsza z analizowanych przeze mnie kalekich strategii mieści się w wirtualnej przestrzeni kalekiej/queerowej teorii, pozostałych pięć jest zlokalizowanych w konkretnych miejscach, w których aktywiści działali na rzecz wzmocnienia i scentralizowania niepełnosprawności w opozycji do postępującej

7 W oryginale użyte jest sformułowanie "sociality", oznaczające nieokreśloną społeczność (society), tj. zbiór lub grupę osób, lecz raczej strukturę oraz typy relacji społecznych. Pojęcie to jest z tego powodu konsekwentnie tłumaczone jako "socjalność" [przyp. tłum.].

8 K. Floyd The Reification of Desire, s. 203. 
globalizacji polityki oszczędności. To, co dzieje się w tych odległych przestrzeniach, opiszę jako społeczną rzeźbę, pragnienie niepełnosprawności, świadomy sprzeciw, działania społecznych placówek medycznych oraz jako praktykę przejęcia i teatralizacji. Kiedy Michel de Certeau analizuje opór, odwołuje się wprost do "różnorodnych, niepokornych, przebiegłych i uporczywych [procedur] - które wymykają się dyscyplinie, pozostając jednak w polu jej działania”. Zgodnie z tą wykładnią de Certeau mógłby opisać sześć kalekich praktyk, które będę tu charakteryzował, jako "plenienie się procedur”, „Wzmocnienie nielegalności” albo „skrytą twórczość, jaka istnieje wyłącznie w zaburzonych dziś urządzeniach i dyskursach obserwującej ją władzy" państwa ${ }^{9}$. Okrzyk z wiecu z 2011 roku „No es una crisis, es una estafa” [To nie kryzys, to oszustwo], którym zakończyłem pierwszy rozdział, podważa lub delegitymizuje neoliberalny stan (w każdym tego słowa znaczeniu) i wspiera wszystkie taktyki, które analizuję.

\section{Taktyka 1. Queerowanie kalekiego oporu i okaleczanie queerowego sprzeciwu}

W tym rozdziale zajmuję się niepełnosprawnością w odniesieniu do pojęcia kluczowego dla całej książki, a mianowicie o p o r u. W niniejszym podrozdziale będę analizował, jak do teoretycznej zmienności tego terminu odnoszą się badacze queer i niepełnosprawności - sam uznaję ich działania za jedną z taktyk oporu. O p ó r miał skomplikowaną historię w krytycznej teorii kultury, szczególnie w badaniach nad queer. Przez jakiś czas, jeden z nurtów koncepcji queer był oparty na pracach filozofa Michela Foucaulta, który wyrażał teorię nieuniknionego lub koniecznego oporu. „Tam, gdzie jest władza, istnieje też opór”, napisał w słynnym zdaniu Foucault. „Z pewnością strategiczny kod owych punktów oporu umożliwia rewolucję"10. Kiedy to, co określamy jako teorię queer, zaczęło powstawać w latach 90., David Halperin w książce Saint Foucault: Towards a Gay Hagiography wskazywał, czym może być Foucaultowski (queerowy) opór. Szczegółowo charakteryzując sposoby, w jakie praca filozofa umożliwia rozumienie władzy jako nie zawsze i nie wszędzie represyjnej, lecz również produktywnej, Halperin podkreślał, że „c e l e m

9 M. de Certeau Wynaleźć codzienność. Sztuki działania, przeł. K. Thiel-Jańczuk, Wydawnictwo Uniwersytetu Jagiellońskiego, Kraków 2008, s. 97-98.

10 M. Foucault Historia seksualności, przeł. B. Banasiak, T. Komendant, K. Matuszewski, Czytelnik, Warszawa 1995, s. 86-87. 
opozycyjnej polityki jest [...] nie wyzwolenie, lecz opór"11. Dla Foucaulta, zgodnie z interpretacją Halperina, marzenie o „wyzwoleniu” z „represji” tworzyło lub wyobrażało przestrzeń istniejącą poza władzą i nie dostrzegało, że język, któremu podlegamy (na przykład język „seksualności”), jest w stanie zmaterializować oraz zabezpieczyć konkretne sposoby bycia i wiedzy, a także zablokować inwencyjność oraz kreatywność.

Czy wyrażenie „pozwólcie nam wyzwolić naszą seksualność” ma sens? pyta Foucault. - Czy wyzwaniem nie powinno być raczej określenie naszych wolnościowych praktyk, przez które moglibyśmy zdefiniować, czym jest przyjemność seksualna oraz czym są nasze erotyczne, miłosne i namiętne związki z innymi? ${ }^{12}$

Queerowa socjalność, która jest głównym przedmiotem zainteresowania Floyda, mogłaby zatem - w tym rozumieniu - nie szukać sposobów na wyzwolenie ukrytej istoty lub prawdy, lecz raczej intencjonalnie tworzyć nowe (odporne) formy przyjemności i relacyjności.

Skupienie na praktykach wolnościowych, które generują innowacyjne formy intymności i faktyczne „życie”, było również charakterystyczne dla tego, jak o p ó r rozumieją studia nad niepełnosprawnością. Najważniejsze prace w tym zakresie, takie jak eseje zebrane w zbiorze Foucault and the Government of Disability Shelley Tremain, często wskazują na sposoby, w jakie domniemana „prawda” niepełnosprawnego życia jest tworzona przez diagnozę, a więc przez pracę czegoś, co Foucault określiłby za pomocą kategorii władzy prawa. Naznaczone przez diagnozę niepełnosprawne podmioty są redukowane do bycia rozumianymi za jej pośrednictwem, a także zawsze i wszędzie zmuszane do mówienia prawdy o swojej patologii. Ta patologia i tylko ona, jak powiedziałaby władza prawa, decyduje o tym, jak wygląda niepełnosprawność. Ponownie jednak, choć wydaje się, że władza, a zwłaszcza autorytet medyczny, musi mieć zawsze negatywne lub represyjne skutki, to może ona również wytwarzać podmioty, które działają inaczej. Tremain pisze, że:

jednostki i prawnie skonstruowane grupy jednostek odpowiadały na praktyki podporządkowywania, które w coraz bardziej intymny

\footnotetext{
11 D. Halperin Saint Foucault: Towards a Gay Hagiography, Oxford University Press, Oxford 1995, S. 18. 
i bezpośredni sposób są związane z „życiem”, przez formułowanie potrzeb oraz żądań tego samego „życia” jako podstawy politycznych kontrpostulatów, a więc odwracały je na potrzeby oporu. ${ }^{13}$

Wolnościowe praktyki oporu są powtarzane albo konstruowane jako konieczne w praktycznie wszystkich znanych sloganach globalnych ruchów osób niepełnosprawnych. Jeśli władze medyczne uprzedmiotawiają prawnie skonstruowane grupy niepełnosprawnych, jeśli w wyniku tego uprzedmiotowienia grupy te spotykają się z litością ze strony pełnosprawnych, a nawet są zachęcane, by zakończyły swe życie w tym i wspomagane (w coraz większej liczbie krajów), to działania te prowokują do zbiorowych odpowiedzi, takich jak: „Nic o nas bez nas”, „Lej na litość, ,,Pomoc w życiu, nie pomoc w śmierci”. Hasło „Tak wygląda niepełnosprawność" prezentuje się tu jako oporowe kontrżądanie komplikujące to, co wyglądałoby na (zgodnie z terminami Tremain) „to samo «życie»”.

Pilna potrzeba takich kontrżądań, zwłaszcza gdy indywidualnie i zbiorowo ożywiają one tych, którzy byli wcześniej uprzedmiotowieni jako niepełnosprawni, podkreśla przekonanie Halperina, że „taki radykalizm nie jest wyłącznie radykalizmem na własne potrzeby, ciekawym dodatkiem do wszystkiego, co może wyglądać na nowe w politycznych i osobistych modach"14. Mimo to w ciągu dwudziestu lat po wydaniu Saint Foucault, wraz z rozwojem teorii queer zdobywającej uznanie i rozpoznawalności na uniwersytecie oraz w publikacjach akademickich (które bez wątpienia karmią się tym, co „wydaje się nowe" w intelektualnych i politycznych modach), konkretny, gęstniejący o p ó r, który m o ż e być opisany jako „radykalizm dla własnych potrzeb”, stał się ewidentny. Podejmowana w dobrej wierze krytyka włączania głównego nurtu ruchu LGTB w ramy państwa i kapitału ma swoją drugą stronę w postaci tęsknoty za poniekąd niewinną figurą "oporu”.

Bobby Benedicto w swoim studium Under Bright Lights: Gay Manila and the Global Scene tropi obie strony tej zagadki w teorii queer:

Rzeczywiście wiele prac na temat tego, co można by określić jako queerowy współudział, skupiało się na tym, jak biali

13 S. Tremain Foucault, Governmentality, and Critical Disability Theory: An Introduction, w: Foucault and the Government of Disability, ed. by S. Tremain, University of Michigan Press, Ann Arbor 2005, s. 7 (wyróżnienie w oryginale). 
homoseksualni mężczyźni (albo połączone figury białości i homoseksualności) są zamieszani w praktyki wykluczania oraz osadzania się w rynkowym kapitalizmie. To ważny punkt zainteresowania, ale jestem ostrożny wobec tego, do czego pośrednio lub bezpośrednio prowadzi, to znaczy wobec listy abstrakcyjnych, wyizolowanych figur: queera, queera $\mathrm{z}$ trzeciego świata, niepełnosprawnego queera, queera $\mathrm{z}$ klasy pracującej, i tym podobnych, w które - ze względu na ich wartość wynikającą z wykluczenia - inwestuje się potencjał transgresji oraz z którymi wiąże się nadzieję na wciąż radykalną politykę. ${ }^{15}$

Ważny projekt Benedicto próbuje zatem odejść od abstrakcji, zwłaszcza przez wycofanie „queera z Trzeciego Świata” (postać osadzoną w Filipinach i wyobrażającą sobie siebie jako uczestnika globalnej sieci gejów) z przestrzeni niewinności: „queer z Trzeciego Świata nie jest wyłącznie innym, ale jest innym, który tworzy własnych innych: znajduje się w centrum miasta i na marginesie świata”16. „Jego inni” w Manili z Under Bright Lights są często niepokojącymi, niepełnosprawnymi figurami: ,jak wtedy, gdy geje jeżdżą w nocy po klubach i unieruchomieni nagle na ulicy, muszą stawić czoło żebrakom starym i ślepym mężczyznom i kobietom z wyciągniętymi plastikowymi kubkami oraz laskami, którymi lekko stukają o koła"17. Ten fragment stanowi element tego, co podlega krytyce: niewidomi zostali uprzedmiotowieni, zamienieni w innych, choć oczywiście Benedicto w ten właśnie sposób chciał skonstruować tę scenę - już budowa zdania pokazuje to, co chciał opisać: myślnik wskazuje na włóczęgów zamienionych w przedmioty. Główny punkt jego krytyki pozostaje jednak niezmienny: jeśli jakakolwiek teoria queer sprowokowała lub skonstruowała figurę queera z Trzeciego Świata jako kogoś, z kim „wiąże się nadzieję na wciąż radykalną politykę", to takie twierdzenie należy zawsze poddawać skrupulatnej kontroli. Under Bright Lights w najlepszym razie nie pozwala na obsadzanie niewinności w postaci queera z Trzeciego Świata, a co za tym idzie - w żadnej abstrakcyjnej figurze.

O p ó r, który zgęstniał już w niektórych, teoretycznych tekstach queerowych, zdaniem Benedicto nie jest wcale czymś, do czego należy dążyć:

B. Benedicto Under Bright Lights: Guy Manila and the Global Scene, University of Minnesota Press, Minneapolis 2014, S. 13-14 (wyróżnienie w oryginale).

16 Tamże, s. 11.

17 Tamże, s. 14. 
Chcę zawiesić akademicką potrzebę dostrzegania różnicy i o p o r u oraz podkreślić, że lokalna s p r a w c z o ś ć pracuje również na usługach modernistycznych aspiracji,że może być mobilizowana do tego, by reprodukować centrum na marginesach, że jest konstruowana za pośrednictwem materialnego otoczenia oraz ożywiana przez siłę narracji o postępie i modernizacji. ${ }^{18}$

Warto jednak podkreślić, że s a mo dostrzeganie różnicy i oporu jest już podważeniem Foucaultowskiego oporu, jak pokazuje studium Halperina. Dzieje się tak, ponieważ dostrzeganie figury, identyfikowanie jej i pokładanie w niej wiary wyposaża ją w substancję lub istotę, która jest nieprawdziwa, zgodnie z tym, jak działa władza w Foucaultowskim sensie. Dostrzeganie różnicy i oporu sugeruje, że skoro już je odnaleźliśmy, nie pozostaje nic do zrobienia - można je jedynie podziwiać. Foucault natomiast konsekwentnie odrzucał fantazję o jedynie dostrzeganiu czy nazywaniu tego, co miało być podobno lub inherentnie dobre (i tym samym wyzwalające) albo złe. W słynnym cytacie, który stał się mottem książki Tremain, stwierdza: „Moją tezą jest nie to, że wszystko jest złe, ale że wszystko jest niebezpieczne, a to niezupełnie to samo. Jeśli wszystko jest niebezpieczne, zawsze mamy coś do zrobienia"19. W rozumieniu Foucaulta, skoro identyfikacja/dostrzeżenie, że figura [niewinnego] queera z Trzeciego Świata zawsze będzie niebezpieczna, to uznanie - jak twierdzi Benedicto - „że lokalna s p raw c z o ś ć działa również w interesie modernistycznych aspiracji", jest w istocie aktem oporu. Ponadto pisanie antropologicznego studium o tym, jak d z i a ła współodpowiedzialność (włącznie z tym, jak mogłaby funkcjonować w odniesieniu do prześladujących podmiot kalekich postaci, które sytuują się na marginesie tekstu), jest elementem „czegoś do zrobienia”, możliwości, które zawsze nam pozostają. Moje rozważania nie są po to, by podważyć przekonanie Benedicta na temat zawieszenia akademickiego dążenia do dostrzegania różnicy i oporu, lecz po to, by wskazać, że kiedy w ostatnich dekadach to akademickie działanie powołuje do istnienia kolejne niewinne figury, to nie jest wcale o p o r o w e w tym rozumieniu, jakie przyjmują niektórzy komentatorzy Foucaulta, tacy jak Halperin i Tremain.

18 Tamże, s. 17.

19 M. Foucault On the Genealogy of Ethics: An Overview of Work in Progress, w: tegoż Ethics: Subjectivity and Truth, ed. P. Rabinow, trans. R. Hurley, New Press, New York 1994, s. 256, cyt. za: S. Tremain Foucault, Governmentality, and Critical Disability Theory, motto rozpoczynające książkę. 
Nirmala Erevelles jest - podobnie jak Bobby Benedicto - ostrożna wobec sposobów, w jakie o p ó r może stać się w akademickim dyskursie błyskotliwą, lecz nieefektywną "transgresją":

Dekonstrukcyjny potencjał poststrukturalizmu, wraz z jego nieograniczonymi możliwościami wyobrażania transgresyjnego ciała, uwodzi naukę, co nie umknęło uwagi badaczy zajmujących się studiami nad niepełnosprawnością, którzy wykonali radykalną pracę, tworząc retorykę niepełnosprawności poza ograniczeniami dominującego dyskursu. ${ }^{20}$

W Disability and Difference in Global Contexts Erevelles wskazuje jednak na głębokie przywiązanie do form z bi o r o w e g o oporu: „na przecięciu rasy, klasy, płci kulturowej, seksualności i niepełnosprawności zobaczymy, że zbiorowy opór jest bardziej owocny niż jego indywidualne formy"21. Książka badaczki jest jednym z tekstów definiujących coś, co moglibyśmy określić jako "globalny zwrot" w studiach nad niepełnosprawnością, teraz niezbędny do analiz intersekcjonalnych. Jak sugeruje podtytuł publikacji, Erevelles bardziej ceni „transformację" niż ludyczną „transgresję". Jej książka poszerza również konieczną dyskusję (która do tej pory w studiach nad niepełnosprawnością pozostawała słabo rozwinięta) na temat tego, jak do powstania niepełnosprawności przyczyniają się zniszczenia czynione przez kapitalizm, imperializm i wojny. Badaczka kieruje się ku czemuś, co określa jako „wspólne miejsce oporu"22 i w uzasadniony sposób krytykuje teoretyków, także światowe badaczki feminizmu, którzy nie włączają lub nie potrafią włączyć do swoich prac materialnej analizy niepełnosprawności.

Erevelles postuluje studia nad niepełnosprawnością, które stale analizują niepełnosprawność w relacyjnym, międzynarodowym kontekście. Jej sugestie są dla mnie szczególnie istotne, ponieważ piszę w czasie i o czasie, gdy globalnie, a niekiedy nawet siłą, narzucono zdroworozsądkowe przekonanie o słuszności polityki oszczędności. Jak powinno być jasne po lekturze Crip Times, podzielam zarówno krytykę hegemonicznych form kapitalizmu Erevelles, jak i jej poczucie, że zbiorowy opór pozostaje kluczowy. Zgadzam się również z twierdzeniem, że poststrukturalistyczna teoria, tworząca to, N. Erevelles Disability and Difference in Global Contexts: Enabling a Transformative Body Politics,
Palgrave, New York 2011, s. 12. 
co badaczka określa jako „nieskończone możliwości”, nie będzie wyjątkowo istotna dla oporu. Taka teoria nie będzie również zbyt poststrukturalistyczna, skoro prawdziwe poststrukturalistyczne zainteresowanie niestabilnością znaczenia nie powinno się przekładać na świat nieskończonych możliwości, ale raczej na świat, w którym należy stale badać przenikającą się dyskursywną i materialną konstrukcję ograniczeń.W nieco innym kontekście Sara Ahmed przypomina, że „zgodnie z poststrukturalistyczną krytyką języka nie możemy ufać słowom [...] zwrot poststrukturalistyczny zaczyna się od nieufności zarówno wobec słów, jak i rzeczy" ${ }^{\text {23 }}$. Konieczna nieufność, o której wspomina Ahmed, będzie całkowicie stracona, jeśli przekształcimy poststrukturalizm w coś sprawczego, indywidualistycznego i pozbawionego ograniczeń2 ${ }^{4}$. Charakterystyka Erevelles, która uznaje poststrukturalizm za prąd zachęcający do nieograniczonych możliwości, doprowadziłaby w końcu, jak mówiła Judith Butler, do "odnowienia figury wybierającego podmiotu" i do zignorowania sposobów, w jakie teoria poststrukturalistyczna, którą Erevelles przecież krytykuje, rzeczywiście w z m a c n i a „zbiorową dysidentyfikację, która może doprowadzić do rekonceptualizacji tego, jakie ciała znaczą i jakie ciała mogą jeszcze zaistnieć jako krytyczny punkt zainteresowania"25. Pomiędzy poststrukturalistyczną teorią a rynkiem akademickim, który w istocie może zachęcać do pisania polegającego na wyłącznym wskazywaniu na różnice i transgresje, istnieje różnica. Działanie tego rynku (przed którym ostrzegali zarówno Benedicto, jak i Erevelles) nie powinno jednak przesłaniać znacznie większej, niż wskazują na to badania Erevelles, wspólnej przestrzeni pomiędzy krytycznym zainteresowaniem tekstualnością, dyskursem a niepewnymi znaczeniami oraz marksistowskim materializmem i zbiorowym oporem, które opisuje Disability and Difference in Global Contexts ${ }^{26}$.

23 S. Ahmed Open Forum Imaginary Prohibitions: Some Preliminary Remarks on the Founding Gestures of the "New Materialism", "European Journal of Women's Studies” 2008, vol. 15, no. 1, S. 34 .

24 Ahmed odnosi się głównie do nowego materializmu, który określa feministyczny poststrukturalizm jako "materialnofobiczny", naiwnie wierzący w słowa i przez to unikający materialności rzeczy. Choć materializm studiów Erevelles jest bardziej tradycyjny niż marksistowski, jej rozumienie poststrukturalizmu czasami naśladuje to, co Ahmed określa jako "karykaturę" poststrukturalizmu widoczną w części nowego pisarstwa materialistycznego. Tamże. J. Butler Bodies That Matter: On the Discursive Limits of "Sex", Routledge, New York 1993, s. X, 4. do Crip Times: „Zamierzam przedstawić kulturową, materialną perspektywę, która łączy poststrukturalistyczne techniki bliskiego czytania i analizy literaturoznawcze - albo pyta, jak język 
Darieck Scott, który twierdzi, że „wszyscy potrzebujemy literackiej wyobraźni", by wzbogacić konwencjonalne formy politycznego oporu i rewolucji, w Extravagant Abjection: Blackness, Power, and Sexuality in the African American Literary Imagination przedstawia takie odczytanie cielesnego i umysłowego cierpienia w pracach Frantza Fanona, które wspiera z a ró w no potrzebę tworzenia „rezerw oporu przed działaniami kolonizatora prowadzącymi do poddania i zniewolenia", ja k i prób uchwycenia tego, co zostanie stracone, kiedy zlekceważy się złożoną pracę języka i tekstualności²7. Analiza Scotta jest kaleka nie wprost, a jego zainteresowanie okaleczonymi ciałami i umysłami

kształtuje oraz przekształca wybór kontestowanych znaczeń - z materialistycznym przywiązaniem do umieszczania (ale nie ustalania) produkcji tych znaczeń - oraz przeciwstawnych tekstów, tożsamości i kultur, które je wyrażają - z ekonomiczną strukturą, procesem i relacjami. Kulturowa perspektywa materialistyczna uznaje te ekonomiczne procesy za jednocześnie ograniczające i umożliwiające kulturową oraz społeczną zmianę, a zarazem nie w pełni determinujące."; por. R. McRuer Crip Times, s. 210. W kontekście Crip Times, warto wskazać, że skromna opozycja między pozornie indywidualistyczną literacką i kulturową produkcją albo performansem (który jest tu rozumiany jako niematerialny lub "ludyczny" - por. N. Erevelles Disability and Difference, s. 12) oraz innymi sposobami zaangażowania w niepełnosprawne życia (które są określane jako bardziej materialne i autentyczne), może być odczytywana jako mimowolnie wspierająca logikę oszczędności (choć nie jest to oczywiście intencja Erevelles). W większości przypadków logika oszczędności - na przykład w edukacji wyższej - była konsekwentnie kierowana przeciwko humanistyce i przybierała postać ograniczeń, jawnych cięć funduszy czy obowiązkowego uzależnienia od pracy zleconej. W trakcie powstawania tej książki cięcia na moim uniwersytecie najmocniej dotknęły program kreatywnego pisania oraz wydział muzyczny.

To jasno wyrażone rozróżnienie na dyscypliny jest słabiej widoczne w studium Erevelles, niż w książce Loneliness and Its Oppostite: Sex, Disability, and the Ethics of Engagement Don Kulicka i Jensa Rydströma, która lekceważąco odnosi się do „profesorów literatury [i] skupienia na reprezentacji" w studiach nad niepełnosprawnością; por. D. Kulick, J. Rydström Loneliness and Its Oppostite: Sex, Disability, and the Ethics of Engagement, Duke University Press, Durham 2015, s. 10. Takie dwuwymiarowe przedstawienie kalekiej teorii przeciwstawia ją szczególnie pracy dotyczącej "rzeczywistych żyć" osób niepełnosprawnych oraz sugeruje, że kaleka teoria "może wstrzymywać skupienie się na poważnych niesprawiedliwościach, z którymi stykają się one na co dzień" (tamże, s. 15, 17). Crip Times, mam nadzieję, dostarcza wyraźnego dowodu, że tak nie jest. Wspomniana książka Kulicka i Rydströma jest gęstym i fascynującym studium seksualności osób niepełnosprawnych w Danii i Szwecji, a także stanowi ogromny wkład w interdyscyplinarne badania nad niepełnosprawnością. Kwestionuję jednak wyrażoną w niej potrzebę dyscyplinującej hierarchii, którą tworzą autorzy, ponieważ polityka oszczędności w nauce już opiera się na przekonaniu, że dziedziny związane z kreatywnością i kulturą są mniej poważne niż inne, jak również dlatego, że uderza mnie zasadnicza niesprawiedliwość prób ograniczania złożonych sposobów, w jakie niepełnosprawna wyobraźnia może być wyrażana.

27 D. Scott Extravagant Abjection: Blackness, Power an Sexuality in the African American Literary Imagination, NYU Press, New York 2010, s. 94, 65. 
(którymi zajmował się Fanon w czasie algierskiej rewolucji) może wiele zaoferować studiom nad niepełnosprawnością, zwłaszcza w odniesieniu do kwestii o p or u. Analizując sposoby, w jakie Fanon pisze o swoich pacjentach, Scott zwraca szczególną uwagę na metaforę napiętych mięśni. Fanon, badając ciała złamane lub pobite przez kolonizację i wojny, widział w nich zarówno p o tr z e bę aktywnego, trwałego sprzeciwu wobec kolonizacji, jak i potencjał takiego oporu. Uszkodzone, spięte mięśnie - w odczytaniu Fanona, które proponuje Scott - równocześnie wskazują oraz przewidują: w skazują, co kolonializm i wojny zrobiły oraz przewidują aktywny opór, który te same ciała stawią kolonialnej dominacji. Tezy Fanona można w pewien sposób powiązać z uwagami Erevelles, skoro - jak wskazywałem ona również skupia się, ponad pięćdziesiąt lat później, na tym, że niepełnosprawność jest często skutkiem kolonializmu i kapitalizmu. Podobnie jak Fanon, Erevelles szuka - ponad językiem i tekstualnością - form aktywnego oporu, które obróciłyby się przeciwko temu systemowi.

Tymczasem Scott, choć stale dostrzega, że „potrzeba kontynuacji tego dążenia [aktywnego oporu] jest oczywista"28, zatrzymuje się na języku wstrętu, czarności oraz zranienia, odkrywając w nich inne formy oporu. Paradoksalnie, odnawia o p ó r w tym, co odrzucone ze wstrętem, i za jego pośrednictwem. Jeśli Fanon szybko przechodzi od dosłownego i metaforycznego znaczenia złamanych ciał oraz napiętych mięśni do „krzepkiego samopoparcia, które jest częścią Czarnej Siły [Black Power]"29, to Scott bada, co jest tracone w zbyt pośpiesznym odrzuceniu towarzyskości, w języku, we wstręcie, w czarności, w zranieniu. Choć nie jest to jego zamiarem, Scott odkrywa ableizm tkwiący inherentnie w teorii Fanona, a co za tym idzie w każdej teorii, która wytwarza skomplikowany horyzont literackiej wyobraźni. Postkolonialny podmiot Fanona nie może dostrzegać wartości w zranieniu i złamaniu: opór powstaje wy ł ą c z n i e wtedy, kiedy podmiot przezwycięża swoje językowe przypisanie do wstrętu, czarności i niepełnosprawności. Scott wskazuje jednak na jego kolejne formy, które krążą zawsze wokół sprzeciwu, władzy oraz świadomości, opisywanych przez Fanona. „Blednące blizny” [fading scars], by odnieść się do tytułu wspomnień O’Toole, pozostają dla Scotta trwałymi śladami.

Wspomnienia O'Toole mogą być interpretowane - w zupełnie innej tradycji - jako performujące to, co Scott ujmuje w formie teorii, choć pisarka

28 Tamże, s. 9.

29 Tamże. 
bardziej wprost łączy jego literacką wyobraźnię z (niepełnosprawnym) materializmem Erevelles. Jak pisze O’Toole:

Moje blizny mnie definiują. Zawsze chciałam zorganizować Obóz Blizn, na którym mogłabym uczcić i opłakać swoje blizny razem z innymi niepełnosprawnymi, dla których takie ślady są normalne [...] Na którym moglibyśmy śpiewać, malować, pisać oraz odgrywać nasze historie o bliznach [...] Blizny przypominają mi, że traumy mojej przeszłości zawsze będą mi towarzyszyć, choć jako bardzo już wyblakłe. ${ }^{30}$

Scott najprawdopodobniej twierdziłby, że „Fanon nie ceni tej formy oporu, poza uznaniem jej za ogólny zarys czegoś, co ma się dopiero zrealizować". Wciąż jednak ta pokryta bliznami, poraniona postać, która jest dosłownie niepełnosprawna i nie w pełni sprawcza (choć Scott nigdy jej tak wprost nie nazywa):

posiada interesujące cechy: jest pokonana - pracuje w obrębie klęski i jest nią nasycona w taki sposób, że klęska decyduje o jej tożsamości oraz zasięgu działania - i zarazem wcale niepokonana w tym sensie, że przekracza porażkę oraz przejmuje siłę wynikającą z tego, iż porażka niekoniecznie niszczy i niekoniecznie obejmuje asymilację.31

Badacz używa sformułowania „ekstrawagancki wstręt" do opisania oporu, który wyraża się w złamaniu, ranach i bliznach ${ }^{32}$. W dalszej części tego rozdziału wykorzystuję teorię oporu Scotta (i O'Toole) do wybranych kontekstów, wyrażając ekstrawaganckie odrzucenie kalekich taktyk kierowanych przeciwko polityce oszczędności.

Polityka oszczędności również generuje ekstrawagancki wstręt, dosłownie raniąc ciała i umysły, a później metaforycznie podwajając to zranienie przez wskazywanie na blaknące blizny oraz upieranie się, że jedyne, na co zasługują, to oszczędność, skoro nie mają one żadnej wartości i podobno żadnej wartości też nie wytwarzają. Kaleka/queerowa teoria oporu, którą tu stosowałem, sama również jest kaleką strategią, która sprzeciwia się zarówno

\footnotetext{
30 Tamże, s. 46-47.

31 Tamże, s. 70-71.

32 Tamże, s. 10.
} 
takim oszczędnościowym sposobom myślenia, jak i oszczędności jako polityce ekonomicznej. W dalszej części tego rozdziału zwracam się ku temu, co identyfikuję jako kaleką - w szerokim rozumieniu tego słowa - socjalność w Stanach Zjednoczonych, Chile, Hiszpanii, Grecji i Wielkiej Brytanii oraz analizuję sposoby, w jakie podmioty zbiorowo zatrzymują się nad bliznami, zranieniem i niepełnosprawnością. W rozumieniu Scotta przejmują one siłę, której porażka nie unieważnia i która niekoniecznie polega na asymilacji. Dekonstrukcyjny potencjał języka i dążenie do znajdowania wartości w odrzuceniu pracuje w każdej z tych taktyk, którymi będę się zajmował, r a z e m i z a p o m o cą bardziej rozpoznawalnych oraz czytelnych zbiorowych praktyk oporu - koniecznych, by przeciwstawić się oszczędności.

\section{Taktyka 2. Kaleki obóz/Rzeźba społeczna}

Zanim ruch Occupy zaczął okupować i zanim Los Indignados stali się oburzeni, na wysepce na skrzyżowaniu w Berkeley w Kalifornii aktywiści stworzyli (kaleki) obóz Arnieville, by protestować przeciw masowym cięciom świadczeń, które wprowadził rząd Arnolda Schwarzeneggera, republikańskiego gubernatora stanu. Arnieville, opisane przez Petrę Kuppers jako „obóz aktywistów i miasteczko namiotów wzniesione przy współpracy niepełnosprawnych, biednych oraz bezdomnych", powstało późną wiosną i wczesnym latem 2010 roku, by głosić: „Cięcia zabijają, a podatki ratują życie. Współzależność, nie niezależność"33. Podobnie jak w przypadku Obozu Blizn, którego wyobrażenie opisuje O'Toole, niepełnosprawne ciała były normą w tej wiosce wzniesionej naprzeciwko supermarketu Berkeley Bowl, posiadającej ogromną figurę Schwarzeneggera z uniesionym toporem. Kuppers określała to miejsce jako w pewnym sensie toksyczne, ze względu na spaliny i hałas wynikający z ruchu samochodowego. Sytuacja w Kalifornii była toksyczna również w bardziej metaforycznym sensie tego słowa: nad niepełnosprawnymi wisiał tam topór i to z tego powodu aktywiści zajęli wysepkę oraz nazwali ją Arnieville. Działacze sprzeciwiali się przede wszystkim cięciom, które likwidowały pomoc asystentów dla 400 tysięcy mieszkańców Kalifornii. W czasie ośmioletniej kadencji Schwarzeneggera (w latach 2003-2011) polityka oszczędności objęła wiele form pomocy dla osób niepełnosprawnych i starszych (grupy

33 P. Kuppers Introduction, w: Somatic Engagement, ed. by P. Kuppers, ChainLinks, Oakland 2011, S. 15 . 
te w pewnym stopniu oczywiście się pokrywają), prowadząc do zmniejszenia publicznych wydatków o 500 milionów dolarów.

Cięcia w Kalifornii (oraz innych stanach) stały się już pewną strategią klasową, w wyniku której ciężar domniemanego „kryzysu” ponoszą najbardziej bezbronni, a bogaci są chronieni przez luki podatkowe oraz łatwy dostęp do sprywatyzowanych świadczeń i usług finansowych, pozostających poza zasięgiem biednych. W 2010 roku (jak również obecnie) w Kalifornii mieszkało równocześnie najwięcej osób niezwykle majętnych i obywateli żyjących w biedzie (jedna na cztery, prawie jedna czwarta populacji), a wraz z pogłębianiem się kryzysu bogaci stawali się coraz bogatsi ${ }^{34}$. W 2013 roku liczba osób ultrabogatych, z majątkiem wartości 30 milionów dolarów, wynosiła tam 12560 (w Nowym Jorku, drugim najbogatszym stanie, mieszkało 8945 osób należących do tej grupy) $)^{35}$. Poza zwróceniem uwagi na redystrybucję klasową (a więc reinwestowanie w najbogatszą grupę) Kruppers sugeruje, że kaleki obóz wskazywał - co było ważnym efektem jego działania - na problem różnic klasowych w bardziej codzienny sposób: „Arnieville zmieniło moje postrzeganie osób bezdomnych, które widzę w okolicy - dzięki niemu część z nich znam obecnie po imieniu ${ }^{36}$.

Nazywam analizowaną tu strategię „obozem kalek”, by podkreślić jej anachroniczny związek z obozami, które stały się bardziej widoczne w roku 2011 (na Puerta del Sol w Madrycie, na Wall Street w Nowym Jorku i gdzie indziej), a więc rok później, ale które były nieco mniej dosłownie lub wyraźnie określane przez związek z niepełnosprawnością (Occupy Wall Street było nawet krytykowane za utrudnienia w dostępie [dla osób niepełnosprawnych - przyp. tłum.]) $)^{37}$. Podkreślając ucieleśnioną relacyjność i radykalną

K. Miles The State with the Most Rich People Also Has the Highest Poverty Rate, "Huffington Post" 15.11.2013, www.huffingtonpost.com (dostęp: 23.10.2015).

Tamże.

P. Kuppers Introduction, s. 17.

W krótkim omówieniu działalności grupy aktywistów Krips Occupy Wall Street (KOWS) Akemi Nishida wskazuje, że choć do obozu Occupy Wall Street mogły się dostać osoby na wózkach, „nie znaczy to jeszcze, że była to przestrzeń dostępna i bezpieczna dla wszystkich. OWS było często zbyt zatłoczone, by się przemieszczać i bardzo przytłaczające. Brak przyjęcia konkretnych rozwiązań sprawił, że nie wszyscy czuli się bezpiecznie. Również szybkie tempo działania było nieosiągalne i niemożliwe do podtrzymania dla wielu". S. Taylor i in. Krips, Cops and Occupy: Reflection form Oscar Grant Plaza, w: Occupying Disability: Critical Approaches to Community, Justice and Decolonizing Disability, ed. by P. Block i in., Springer, New York 2016, s. 25. 
socjalność tej przestrzeni, Kuppers nazywa wioskę „rzeźbą społeczną”38. Jej zdaniem poza i ponad bezpośrednim wpływem Arnieville na legislację w Kalifornii (badaczka jest „sceptyczna” wobec mierzenia sukcesu obozu za pomocą mierzenia wpływu, jaki miał na zmianę polityki) powstała tam „polityka zaangażowania i relacyjności, ucieleśnionego kontaktu oraz wspólnej przestrzeni" ${ }^{\text {39 }}$. Metafora „wspólnej” przestrzeni i przestrzeni dosłownie zajętej przez aktywistów w Berkeley pokazuje po raz kolejny, że kalekie czasy powinny być rozumiane nie tylko temporalnie (czas oszczędności, czas oporu), ale i przestrzennie.

Kuppers jest zarówno badaczką studiów nad niepełnosprawnością, jak i artystką performatywną, która często pracuje z publicznością we włączający, zachęcający do cielesnego zaangażowania sposób. „Rzeźba społeczna” (zarówno w jej pracy performerki, jak i jako to, co zaistniało w Arnieville) odnosi się zatem do:

społecznej somatyki: jest terapią dla świata, wytrąceniem na chwilę $\mathrm{z}$ równowagi czasu i przestrzeni. $\mathrm{W}$ tym rozchwianym czasie, $\mathrm{w}$ trwaniu następującym po tym, jak ci, którzy mówili, zostali przegadani, możemy wspólnie wziąć oddech, po którym pozostanie posmak spalin na naszych językach. ${ }^{40}$

„Rozchwiany czas”, tak, jak wyobraża go sobie Kuppers, funkcjonuje podobnie jak koncept „kalekiego czasu” w tym tekście. Rozchwianie wyraźnie sugeruje odniesienie do niepełnosprawności, szczególnie psychicznej, skoro słowo to jest używane dla opisania "mentalnie niezrównoważonych, obłąkanych". Dokładnie tak, jak użyłem kategorii „kalekiego czasu” by opisać brutalność czasów oszczędności, w których żyjemy oraz wyraźny potencjał, tkwiący w energicznym oporze kalek wobec tego momentu, „rozchwiany czas" Kuppers nie może być rozumiany wyłącznie przez negatywną wartość rozchwiania. Zdaniem aktywistki „rozchwiany czas” - nawet w mgle dosłownej toksyczności, w której sformułowanie to zostało ukute - wytwarza nowe możliwości i żywotną czasowość, pozwalającą ciałom zbierać się razem w innowacyjne sposoby.

38 P. Kuppers Introduction, s. 17.

39 Tamże, s. 16.

40 P. Kuppers Social Somatics, w: Performance Studies: Keywords, Concepts and Theories, ed. by B. Reynolds, Palgrave, London 2014, S. 191. 
Kontynuując swój protest również w czasie rządów Jerry'ego Browna, grupa z Arnieville używała nazwy CUIDO: Communities United in Defense of Olmstead [Społeczności Zjednoczone w Obronie Olmstead], która w języku hiszpańskim znaczy również „obchodzi” albo „obchodzi mnie”. CUIDO oficjalnie stwierdza, że postępujące cięcia budżetowe w Kalifornii

groziły zamknięciem w ośrodkach osób z niepełnosprawnościami lub starszych wbrew ich woli i z pogwałceniem Olmstead, wyroku Sądu Najwyższego w sprawie Amerykanów z Niepełnosprawnościami, stanowiącego, że niekonieczna izolacja osób z niepełnosprawnościami jest dyskryminacją ze względu na niepełnosprawność. ${ }^{41}$

Działania CUIDO z konieczności wyszły poza wysepkę w Berkeley (podobnie jak rok później ruch Occupy Wall Street rozszerzył się poza Zuccotti Park na Manhattanie). Organizowano marsze i demonstracje w różnych miejscach, a pod hasłem „CUIDO żąda naszych praw” grupa uczestniczyła w kampanii „This Is What Disability Looks Like”. CUIDO przeniosło się również do świata wirtualnego, dzięki czemu zaczęło się zajmować kwestiami wykraczającymi poza amerykańskie prawodawstwo. Elastyczność nazwy CUIDO pozwala na odczytywanie „kalekiego obozu” niekoniecznie jako fizycznej przestrzeni, ale raczej jako zaraźliwej oraz trwałej praktyki oporu oraz wolności, która może być odnawiana gdziekolwiek i jakkolwiek jest potrzebna: wprawdzie po hiszpańsku „cuido" to stwierdzenie w pierwszej osobie liczby pojedynczej, ale nazwa grupy wskazuje na zbiorową, rozdrobnioną $\mathrm{i}$ inwencyjną społeczną praktykę ${ }^{42}$. Taka zmienność kształtu jest jedną z najważniejszych strategii aktywistów niepełnosprawności. Akronim radykalnej grupy ADAPT ${ }^{43}$ znaczył co innego w różnym czasie i miejscu, zgodnie z tym,

41

CUIDO (Communities United in Defense of Olmstead, cuido-arnieville.blogspot.com (dostęp: 23.10.2015).

W rozdziale 3 analizuję sposoby, w jakie studenccy aktywiści w Meksyku używali frazy "Yo Soy" ["Jestem"] w podobnie szerokim, nie jednostkowym i zbiorowym sensie.

We wczesnych latach 80. akronim ADAPT oznaczał American Disabled of Accessible Public Transport [Amerykańscy niepełnosprawni za dostępnym transportem publicznym], w roku 1990 zmienił się na American Disabled for Attendant Programs Today [Amerykańscy niepełnosprawni za aktualnymi programami wsparcia] (por. D.Z. Fleischer, F. Zames The Disability Rights Movement: From Charity to Confrontation, Temple University Press, Philadelphia 2001, s. 82). Zmiany ADAPT nie są w żaden sposób połączone z grupą solidarnościową AIDS Coalition to Unleash Power (ACT UP), która w 1989 roku na demonstracjach pod ratuszem w Nowym 
co działacze uznawali za palącą potrzebę w konkretnym momencie ${ }^{44}$. Kalekie rzeźby społeczne są adaptacyjnymi praktykami performatywnymi, a jako takie będą zawsze - równocześnie - cielesne i widmowe, materializujące się w jednostkowe i kreatywne sposoby w odmiennych czasach i miejscach.

\section{Taktyka 3. Pragnąc niepełnosprawności: Huelgas de Hambre}

Protest przeciwko oszczędnościom w Madrycie miał swój specyficzny odpowiednik latem 2011 roku na południowej półkuli: była to tak zwana Chilean Winter [Chilijska Zima]. Chilijski ruch studentów, który przykuł uwagę świata niedługo po powstaniu hiszpańskiego ruchu \#15M nie był skupiony na polityce oszczędności (i w rzeczywistości chilijska gospodarka była wtedy w okresie żywotności oraz „rozkwitu”). Zamiast tego, koncentrował się na konkretnej neoliberalnej polityce, zajmującej się systemem edukacji - systemem, który wiele osób postrzegało jako najbardziej znaczącą pozostałość po dyktaturze Augusto Pinocheta i przemocowych początkach neoliberalizmu w tym kraju. Chilijskie kształcenie wyższe było jednym z najdroższych i najbardziej nierównych na świecie, a rząd prawicowego prezydenta Sebastiána Piñery chciał zwiększyć czesne na studiach. W obliczu tej podwyżki ruch studencki, zapoczątkowany przez charyzmatycznego Camilla Vellejo (członka Komunistycznej Młodzieży Chile i wcześniejszego przewodniczącego Federacji Studentów Uniwersytetu Chilijskiego), zażądał czegoś przeciwnego - no es una crisis, es una estafa [to nie kryzys, to oszustwo] - by edukacja była darmowa i dostępna dla wszystkich.

Ruch zmierzający do reformowania chilijskiej edukacji na wszystkich szczeblach został zainicjowany tak naprawdę wcześniej, za czasów poprzedniego rządu i centrolewicowego prezydenta Michelle Bacheleta w roku 2006, w trakcie wydarzenia, które określano jako "marsz pingwinów" (nazwa ta wynika z mundurków, które noszą uczniowie szkół średnich w Chile). Marsz pingwinów (lub: rewolucja pingwinów) żądał darmowego transportu

Jorku używała akronimu CHER. Aktywiści nosili wtedy koszulki z jedwabnymi nadrukami z piosenkarką Cher, ale znaczenie akronimu zmieniało się w toku akcji - od "Commie Homos Engaded in Revolution" [komunistyczni homoseksualiści zaangażowani w rewolucję] do "Cathy Has Extra Rollers" [Cathy ma dodatkowe kółka]; por. D. Crimp, A. Rolston AIDS DemoGraphics, Bay Press, Seattle 1990, s. 20. ADAPT i ACT UP są produktami czasów ucieleśnionego aktywizmu w USA i nawet bez wyraźnych związków między tymi dwiema grupami warto odnotować podobieństwa oraz równoczesną kreatywność. 
do szkół i zakończenia praktyki dotowania prywatnych placówek drugiego szczebla, która wpływała na utwardzenie nierównego systemu: bogaci uczniowie chodzili do subsydiowanych szkół z bogatymi uczniami, a biedni i z klasy pracującej do szkół publicznych, w które rząd inwestował o wiele słabiej (publiczne środki były więc w praktyce kierowane do szkół prywatnych, przeznaczonych w zasadzie wyłącznie dla klas wyższych i wyższej klasy średniej). Najważniejszym żądaniem marszu była porządna edukacja dla wszystkich, a protesty z roku 2011, skupiające się raczej na szkolnictwie wyższym, kontynuowały i poszerzały te działania. Kiedy sam przyjechałem do Santiago dwa lata później, przed wiosennymi wyborami, które zmiotły partię Piñery z urzędu i wyniosły z powrotem na to samo miejsce Bacheleta (wraz $\mathrm{z}$ wieloma liderami ruchu studenckiego, wybranymi do parlamentu, włącznie z Vallejo), to stałe żądanie było wciąż wyraźnie obecne, włącznie z graffiti krzyczącymi „Educación Gratis Ahora” [Darmowa Edukacja Natychmiast!], widocznymi na murach w całym mieście. Chilijskie wystąpienia z roku 2011 nie prezentowały się od razu jako ruch na rzecz niepełnosprawności (i wciąż nie są tak postrzegane przez większość osób nim zainteresowanych). Jednak obrazy niepełnosprawności zaczęły towarzyszyć rozwojowi ruchu na arenie międzynarodowej, gdy kilkoro zaangażowanych studentów - wspierających protesty - zainicjowało strajk głodowy, trwający ponad dwa miesiące. Strajk rozpoczął się 19 lipca 2011 roku, od 9 studentów z Buin w Santiago, a prawie dwadzieścia kolejnych osób z całego kraju dołączyło w następnych dniach. 15 sierpnia trzech protestantów z Buin zaostrzyło głodówkę, odmawiając przyjmowania również płynów ${ }^{45}$.

Mimo że kalekie obrazy nigdy nie stanowiły centrum przekazu medialnego, to z powodu strajku głodowego zaczęły pojawiać się w prasie, na marginesie doniesień na temat protestów w Santiago i w reszcie kraju. Głodujący studenci uczestniczyli w manifestacjach na wózkach inwalidzkich, często pchanych przez swoich towarzyszy ${ }^{46}$. Jeszcze bardziej wszechobecne były przedstawienia masek, noszonych przez strajkujących. Maseczki miały chronić osłabiony głodówką system odporności protestujących (było to szczególnie istotne w Santiago, które - od dnia swojego założenia przez konkwistadorów w XVI wieku - położone jest w dolinie, gromadzącej pył,

45 B. Peterson Chilean Student Hunger Strikers Hold President Piñery Accountable, "Nation" 22.08.2011, www.thenation.com (dostęp: 24.10.2015).

46 Huelga de hambre: Huelgistas marcharon por Santiago, „El Chileno", elchileno.cl (dostęp: 24.10.2015). 
zanieczyszczenia i - w obecnych czasach - spory smog). Zdjęcia wózków inwalidzkich oraz masek pozostały na marginesach globalnej dystrybucji obrazów prawdopodobnie dlatego, że bardziej popularne reprezentacje wizualne podkreślały raczej zmitologizowane zdrowie i wigor. Mimo to huelgistas de hambre pozwalają nam na odmienne podejście do ruchu.

Oficjalne oświadczenie Komisji do Wsparcia Strajku Głodowego [Comisión Apoyo Huelgistas] zawierało zdjęcie czwórki studentów w maskach, z napisem „Estudiantes en Huelga de Hambre” [Studenci podczas strajku głodowego], obok słów (zapisanych wielkimi literami) „Ni Un Minúto Solos" [Nawet przez minutę nie pozostawieni sami] ${ }^{47}$. Grupa chilijskich artystów hip-hopowych - Portavoz, Profeta Marginal, MC Erko oraz Raza Humana - wyprodukowała i rozpowszechniła nagranie wideo o tym samym tytule, rozszerzające znaczenie słów „Nawet przez minutę nie pozostawieni sami". Jeśli w fotografii fraza ta wyrażała zarówno solidarność między głodującymi, jak i dosłowną ochronę zdrowia (strajkujący nie zostawali nigdy sami, ponieważ ich potencjalnie podupadające zdrowie wymagało ciągłej obserwacji), w nagraniu ta solidarność z postępująco niepełnosprawnymi głodującymi wybrzmiewała - wraz z muzyką - szerzej i dalej: w kierunku chilijskiego ruchu protestującego jako całości, chilijskich artystów wspierających grupę i (w pewien sposób) innych, globalnych ruchów, działających w tamtym momencie. I rzeczywiście, identyczne transparenty były widoczne na niektórych protestach zarówno w Santiago, jak i Madrycie: widziałem protestujących owiniętych w chilijskie flagi, określających samych siebie jako "Chilean Indignados” [Chilijscy Oburzeni] w Puerta del Sol w Madrycie w sierpniu 2011 roku, a transparenty, które pojawiły się w Chile w tym samym miesiącu, były również używane w Madrycie, oznajmiając (na przykład): „Si Jesús estuviera aquí..." [Gdyby Jezus tu był...], maszerowałby $\mathrm{z}$ nami, bo również był biedny.

Portavos, we fragmencie otwierającym „Ni Un Minúto Solos”, deklaruje:

La democracia es un fraude gigante

Niños y apoderados dando una huelga de hambre

Po una education gratis donde su calidad

No dependa de tu bolsill, tu apelliido o nido social

4718 de Septiembre, represión y una huelgista detenida: Nada que celebrar!, notascect.wordppress. com (dostęp: 24.10.2015). 
[Demokracja jest potężnym oszustwem

Dzieci i ich opiekunowie zaczęli strajk głodowy

Za darmową i dobrą edukację

Która nie zależy od twojego portfela, nazwiska czy klasy]

Nagranie zaczyna się od migających cyfr, wskazujących na dni strajku głodowego, a później pokazuje kilkoro studentów w maskach, siedzących razem na podłodze. Pulsujące liczby poprzedzają i zapowiadają rytm Portavoza, a dalsza część składa się ze zmontowanych obrazów, włączając w to zdjęcia z protestów i polityczną kreskówkę wymierzoną w Piñerę. Jedna z fotografii przedstawia policję zbliżającą się do protestującego, który trzyma tom z napisem „Tiene un libro! Tiene un libro!” [Ma książkę! Ma książkę!]. Pojedyncze zdjęcia ukazują głodujących w maskach z podpisami: Karla, pięćdziesiąty dzień bez jedzenia; Francisco, głodujący dla wykształcenia, i tak dalej.

Interesuje mnie kilka aspektów tych przedstawień, pojawiających się od roku 2011 do teraz. Traktując zupełnie poważnie potencjał i nieskończoność rozprzestrzeniania się krzyku, który interesował mnie w pierwszym rozdziale Crip Times, wspomniane obrazy również stanowią o tym ,jak wygląda niepełnosprawność". I ponownie, to również jest - choć w specyficzny sposób niepełnosprawność zaangażowana w obnażanie oszustw oraz skandali. Po drugie, przedstawienia te jeszcze wyraźniej pokazują nam niepełnosprawność uwolnioną z konkretnej polityki tożsamości, silnie widzialną i łatwą do odczytania (przynajmniej dla części aktywistów oraz teoretyków) w takich krajach, jak USA. Po trzecie - być może zwodniczo - pasja aktywistów oraz ich zaangażowanie, które przedstawiają te obrazy, jest strategiczna i zaraźliwa, a równocześnie realna, p o żą d a j ą c a lub pragnąca niepełnosprawności, którą przyjmuje się w interesie całego ruchu aktywistycznego jako sposób na rozszerzenie jego tożsamości. Strajki głodowe z roku 2011 zakończyły się w końcu, kiedy Piñera został usunięty, ale studenci wpisali swoje ciała w szerszy ruch, mający na celu darmową i dostępną edukację. Przegrana Piñery była postrzegana jako ważny krok w stronę realizacji tych postulatów.

Publiczne oblicze ruchu zmieniło się jednak gwałtownie jesienią i zimą 2015 roku. Chociaż rząd Bacheleta deklaratywnie popierał wolną oraz dostępną edukację dla wszystkich, a nawet sugerował początkowo, że można ją będzie wprowadzić w roku 2016, ruch studencki był niezadowolony zarówno z tempa reform, jak i z faktu, że ich żądania mogłyby zostać wypaczone (w sposób, który utrwaliłby i nawet wzmocnił głębokie podziały klasowe, które do tej pory charakteryzowały system). Z tego powodu protest był kontynuowany 
w Santiago, Valparaíso i w innych miejscowościach w Chile, a policyjne represje wobec strajkujących zaczęły eskalować. Kiedy obserwowałem taki protest 1 czerwca 2015 roku, nagle musiałem uciekać ze studentami przed naporem policji i armatek wodnych, które pojawiły się bez ostrzeżenia, by rozpędzić demonstrację. Tym, co uczyniło tę radykalną interwencję nawet bardziej szokującą, był fakt, że w tamtym czasie jeden ze studentów dopiero przebudził się ze śpiączki w szpitalu Viña del Mar, blisko Valparaíso. 21 maja 2015 roku Rodrigo Avilés uczestniczył w proteście w nadmorskim Valparaíso, podczas którego użyto armatek wodnych do rozpędzenia demonstracji. Policja została przyłapana - na nagraniu wideo - na umyślnym celowaniu armatką wodną z bardzo bliskiej odległości do Avilésa, kiedy ten poruszał się z grupą studentów po chodniku. Mężczyzna doznał poważnych uszkodzeń głowy, gdy uderzył o chodnik. W efekcie miał uszkodzoną prawą stronę mózgu i by ratować jego życie wprowadzono go w śpiączkę farmakologiczną. W czasie zimy student przeszedł kilka operacji i rozpoczął długi proces rehabilitacji, którego szczegóły były szeroko raportowane przez chilijskie media. Równocześnie poza szpitalem, w całym kraju i w mediach społecznościowych, ruch zaczynał się łączyć wokół historii Avilésa oraz związanych z nią obrazów. Wideo przedstawiające zdarzenie i inne nagrania, zawierające między innymi zeznania świadków, były szeroko rozpowszechniane.

Wybudzony ze śpiączki pod koniec maja 2015 roku, Rodrigo Avilés był leczony jeszcze przez kilka tygodni i ostatecznie wypisano go ze szpitala 21 lipca. Zdjęcie z tego dnia stało się symbolem ruchu i było w Chile szerzej rozpoznawalne, niż jakakolwiek fotografia z roku 2011 ${ }^{48}$. Przedstawiało Avilésa z czerwonym szalikiem owiniętym wokół brody, stojącego w szpitalnym pokoju z chilijską flagą, na której widać napis „Rendirse Jamás!!” [Nigdy się nie poddawaj!!]. Ponownie: tak też wygląda niepełnosprawność, choć - jak twierdzę - ruch studentów w Chile nie był (i wciąż nie jest) interpretowany jako ruch "niepełnosprawnych"49. Jednak obraz Rodrigo Avilésa, niespodziewanie wspierający wcześniejsze fotografie huelgistas de hambre, a nawet, w pewnym momencie w roku 2015 będący główną reprezentacją ruchu, jest

48 M.P. Nuñez Melbourne Comedy Festival Causes Nervous Laughs, "Syndey Morning Herald" 15.03.2014, www.smh.com.au (dostęp: 14.09.2015).

49 Jestem bardzo wdzięczny Cristianowi Iturriadze za kilka ważnych rozmów na temat ruchu studenckiego w Chile, jak również za regularne informacje na temat tamtego aktywizmu i problemów związanych z niepełnosprawnością. Wszystkie ewentualne błędy w interpretacji działań ruchu są skutkiem wyłącznie moich uchybień. 
tak samo kaleki, jak każde inne przedstawienie, wyrastające z różnorodnego ruchu oporu, który stał się globalnie rozpoznawalny w roku 2011.

\section{Taktyka 4. También Soy Inmigrante: sprzeciw sumienia}

Jak sugerowałem we wstępie do Crip Times, od kiedy rząd Mariano Rajoya przejął władzę w Hiszpanii pod koniec 2011 roku, realizował on jedną z najbardziej radykalnych polityk oszczędnościowych w Europie. Od roku 2014, zarówno Partia Ludowa [Partido Popular, PP] Rajoya, jak i Hiszpańska Socjalistyczna Partia Robotnicza [Partido Socialista Obrero Español, (PSOE)] były kontrapunktowane przez Podemos [Możemy], antyoszczędnościową partię, sprzeciwiającą się cięciom (jej pojawienie się było, wedle niektórych analiz, bezpośrednim skutkiem mobilizacji wywołanej przez \#15M). Choć „zdroworozsądkowa” zgoda wspomnianych dwóch grup na trwałą oraz coraz bardziej dotkliwą politykę oszczędności była podważana przez Podemos, wciąż pozostaje niejasne, czy i jak partia ta wpłynie na przyszłą hiszpańską politykę, zwłaszcza po tym, jak Rajoy został ponownie mianowany na premiera w roku 2016. Podobnie jak cięcia w Kalifornii oraz podwyżki czesnego w Chile, polityka PP była wymierzona w ciała najsłabszych, będące symbolami zbędnych wydatków, koniecznych do ograniczenia, by zmniejszyć kryzys ekonomiczny. PP połączyła te bezbronne ciała w zmaterializowanie grupy, które miały być zarządzane przez marginalizację, wykluczenie lub usunięcie. Badiou nazywał te wrażliwe ciała, które „są obecne w świecie, ale nieobecne w jego znaczeniach i w decyzjach dotyczących przyszłości, n i e i s t n i e j ą cy $\mathrm{mi}$ tego świata"50.Zdaniem filozofa, zmiana rozpoczyna się i staje się „realna”, „kiedy nieistniejący tego świata zaczynają funkcjonować w tymże świecie z maksymalną intensywnością"51. Czwarta kaleka strategia z czasów polityki oszczędności, którą dosłownie cytuję [w tytule tego podrozdziału - przyp. tłum.], przyjmuje oraz rozpoznaje nieistniejących w chwili, kiedy państwo odmawia im tego gestu, a nawet kryminalizuje tych, którzy go pragną.

Rajoy i jego partia wprowadziła od 1 września 2012 roku nowe prawo (zapowiedziane wcześniej, latem tego samego roku): Rey Decreto Ley 16/2012 [Dekret królewski, prawo nr 16/2012], odmawiające opieki medycznej imigrantom bez dokumentów. Had Joseph, jako „Brazilian Beach Boy” z projektu This Is What Disability Looks Like, który omawiałem w pierwszym

\footnotetext{
50 A. Badiou The Rebirth of History, trans. G. Elliott, Verso, London 2012, s. 56. 
rozdziale Crip Times, przebywał w Hiszpanii w momencie, kiedy pojawiły się nowe zasady, bezpośrednio go dotykające (status prawny Josepha jako pracownika-imigranta został zatwierdzony w USA dopiero na początku roku 2014). Prawo stanowiło, że imigrantom nie należy udzielać pomocy medycznej w państwowych szpitalach, jeśli nie posiadają hiszpańskiej karty stałego pobytu ${ }^{52}$. Setki lekarzy w całym kraju podpisało dokument, wskazujący na konflikt sumienia z nowymi zasadami (objetores de conciencia). Katalonia i Kraj Basków, posiadające autonomię pozwalającą na decydowanie o własnej opiece zdrowotnej, postanowiły, że będą „,wciąż udzielać darmowej, podstawowej pomocy medycznej i leków wszystkim, którzy tego potrzebują, bez względu na ich status"53.

Ponownie, polityka tożsamości, choć niezupełnie nieistotna, jest n i e w y s t a r c z a ją c a dla rozumienia znaczeń niepełnosprawności, które cyrkulują wokół neoliberalnego cięcia wydatków w Hiszpanii, ponieważ bezbronne ciała, materializujące się w wyniku omawianego prawa, mogły identyfikować się zarówno jako niepełnosprawne, jak i nie określać siebie w ten sposób. Identyfikacja jest jednak, na kilka różnych sposobów, kluczowa dla kalekich strategii negocjacyjnych i im podobnych, rodzących się ze sprzeciwu wobec dekretu. Po pierwsze, można było zaobserwować odzew ze strony środowiska medycznego, które nie chciało uczestniczyć w cięciach - sprzeciw sumienia dotyczył identyfikowania chorych, rannych albo niepełnosprawnych ciał jako nadmiarowych oraz zbytecznych, koniecznych do wykluczenia. Po drugie, nastąpiła - mimo różnic - i d e n ty fi k a c ja z tymi ciałami i umysłami. Wynikała ona z faktu, że - nawet jeśli na odmienne sposoby - pracownicy służby zdrowia oraz ich sprzymierzeńcy uznali, że wszyscy żyjący w Hiszpanii zostali poddani cięciom i ograniczeniom, albo mówiąc inaczej: stali się obiektami oszczędności. Powstanie Podemos - rok od wprowadzenia dekretu - pokazało, że mobilizacja całej Hiszpanii powołała do życia pierwszą osobę liczby mnogiej („możemy”), a więc podmiot w rozumieniu Badiou, który niekoniecznie dotychczas istniał. Sprzeciw sumienia, tu omawiany, wyprzedza proces upodmiotowienia kalek oraz materializację ekscesywnego "my”, którego polityka oszczędności nie jest w stanie całkowicie zanegować.

Sprzeciwiając się prawu, część aktywistów zaczęła odwoływać się do kategorii „człowieczeństwa”, jako czegoś, co można wybrać. \#yoelijoserhumano

52 F. Govan Spanish Doctors and Nurses Protest over Health Care Law for Immigrants, "Telegraph" 6.08.2012, www.telegraph.co.uk (dostęp: 25.10.2015). 
[wybieram bycie człowiekiem] - głosiła kampania operująca obrazami z ustami zaklejonymi/uciszonymi przez plastry. Usta te nie są koniecznie związane z fotografiami, które omówiłem w pierwszym rozdziale Crip Times: z Ogniem w moim brzuchu Dawida Wojnarowicza, przedstawiającym zaszyte wargi artysty. Usta w \#yoelijoserhumano są zaklejone, ale podobieństwa pomiędzy krytycznym, kalekim wykorzystaniem obrazów w filmie Wojnarowicza z 1986 roku a wysiłkami aktywistów z roku 2012 są dostrzegalne. \#yoelijoserhumano było zwodniczo prostym wezwaniem humanistycznym, które w rzeczywistości odmawiało współuczestnictwa w dominujących formach humanizmu i rehabilitacji, otwierając podmiot - by użyć słów Atheny Athanasiou - na „radykalną reartykulację człowieczeństwa" ${ }^{54}$. „Wybieram bycie człowiekiem" opiera się oczywiście na rozpoznaniu, kto jest w humanizmie włączony w kategorię ludzi (przez implikację, skoro oni rzekomo n i e wybrali człowieczeństwa), a kto nie. Ten podział był jednak od dawna atakowany przez myślicieli krytycznych. Jednak wyzywająco zaprezentowane twierdzenie „wybieram bycie człowiekiem”, które Badiou określiłby jako „część preskryptyw nej rze czywis to ści"55, sugeruje, że „człowieczeństwo" w tym kalekim performansie wynika nie ze zunifikowanej podmiotowości lub obywatelstwa (co było charakterystyczne dla tradycyjnego humanizmu), ale raczej z t a k ty c z n ej i d e n ty fika cj i z poranionymi nieistniejącymi, z tymi, którzy są uciszani i którzy będą dosłownie wyłączani z człowieczeństwa, tak, jak je definiuje obecnie hiszpańskie państwo. Kampania \#yoelijoserhumano przedstawia również - obok zdjęć zaklejonych ust (które, biorąc pod uwagę anonimowość osób na fotografiach, mogą być lub nie być ustami osób niepełnosprawnych) - fakty popierające przekonanie, że można sobie wyobrazić politykę alternatywną wobec polityki oszczędności, idącą w kierunku zbiorowego, kalekiego horyzontu: konkretne wyliczenia falsyfikują przekonanie o „wykorzystywaniu” systemu przez imigrantów. Badania pokazują, że nowe przypadku zakażenia HIV/AIDS wzrosną o 20\% w rezultacie wprowadzenia ograniczeń w dostępie do służby zdrowia, a prawie milion mężczyzn i kobiet como tú [takich jak ty] będzie pozbawiona podstawowego prawa do opieki medycznej z powodu obostrzeń itd..$^{56} \mathrm{Z}$ jednej strony, obrazy

54 J. Butler, A. Athanasiou Dispossession: The Performative in the Political, Polity, Cambridge 2013, S. 34 . cą faktów, jest nieodległy od projektu Liz Crown „In Actual Fact”. „In Actual Fact”, albo \#Actual- 
zaklejonych ust aktywistów są surowe i oszczędne, z drugiej zaś sprzeciwiają się wprost oszczędności reprezentacji, od której zależy hiszpańskie państwo.

\section{Taktyka 5. Odmienne stany: społeczne placówki medyczne}

Żadne państwo, wdrażające politykę oszczędności, nie wpłynęło na proces pisania Crip Times bardziej niż Grecja, kraj silnie zadłużony na arenie międzynarodowej i zmuszony do przyjęcia jednej z najsurowszych form polityki oszczędnościowej w rejonie Unii Europejskiej, bezwzględnie narzuconej przez tak zwaną „troikę": Komisję Europejską (KE), Europejski Bank Centralny (EBC) oraz Międzynarodowy Fundusz Walutowy. Od początku kryzysu w Grecji, Niemcy - zarządzane przez konserwatywną kanclerz Angelę Merkel i ministra finansów Wolfganga Schäuble'go z Unii Chrześcijańsko-Demokratycznej (CDU) - były powszechnie postrzegane jako kraj najpotężniej wpływający na wspomnianą trójkę i nalegający na oszczędności. Troika forsowała żądanie „strukturalnych reform” w Grecji, by ograniczyć jeden z największych światowych długów, a „reformy" były zupełnie czytelnym eufemizmem coraz głębszych oszczędności: pomoc Grecji, kiedy kraj nie był zdolny do spłacenia zobowiązań, została połączona z cięciami w sektorze publicznym (włącznie z natychmiastowymi i jawnymi zwolnieniami pracowników), podniesieniem wieku emerytalnego, cięciem świadczeń, prywatyzowaniem zasobów oraz otwarciem kraju na coraz więcej zagranicznych inwestycji. Podobnie jak w przypadku Hiszpanii, dominujące, centrowe partie, które miały władzę przed rokiem 2015, godziły się z żądaniem oszczędności w i po kryzysie. Alexis Tsipras z Syrizy (Koalicja Radykalnej Lewicy), partii, która zrodziła się jako antyoszczędnościowa w roku 2012, określił te chętne cięciom grupy: Nową Demokrację, Panhelleński Ruch Socjalistyczny (PASOK) i Demokratyczną Lewicę - „domową troiką", po tym, jak wygrały wybory w roku 2012 i zawiązały koalicję. Koalicja ta posiadała władzę w Grecji przez prawie trzy lata.

25 stycznia 2015 roku nowe wybory przyniosły zwycięstwo Syrizie, która stała się pierwszą antyoszczędnościową partią sprawującą władzę w Europie. Charyzmatyczny Tsipras został premierem, a Yanis Varoufakis ministrem finansów. Panagiotis Kouroumblis, niewidomy aktywista,

Fact, pokazują wyliczenia skierowane przeciwko fałszywym informacjom rozpowszechnianym przez brytyjski rząd, jak "cięcia wymierzone w najbiedniejsze 10 procent obywateli są 13 razy większe niż wymierzone w 10 procent najbogatszych \#ActualFact"; por. L. Crown In Actual Fact, inactualfact.org.uk (dostęp: 25.10.2015). Prace Crown analizuję w rozdziale 4. 
którego Tsipras mianował na ministra zdrowia, był pierwszym (otwarcie) niepełnosprawnym Grekiem w rządzie ${ }^{57}$. Kouroumblis był członkiem założycielem Światowego Związku Niewidomych i pracował z innymi grupami niepełnosprawnych, a także ze stowarzyszeniami zajmującymi się pomocą ludziom starszym („Panaghiotis Kouroumblis”). W czasie oszczędności już wcześniej słaby system opieki podupadł zupełnie dla wielu niepełnosprawnych: w przepełnionym i marnie obsadzonym centrum w Lechainie, na południu Grecji, jak przekazywało na przykład BBC, dzieci autystyczne oraz inne dzieci z niepełnosprawnościami były zamykane w klatkach. Warunki te pokazano w czasie globalnego kryzysu ekonomicznego, a grecki rzecznik praw obywatelskich opublikował raport określający te warunki jako "upokarzające”, , nielegalne” $\mathrm{i}$,zupełnie sprzeczne z obowiązkiem szacunku i ochrony praw człowieka"58.

Część personelu w centrach takich, jak w Lechainie, chciała zmian, ale w warunkach oszczędności nie było najzupełniej żadnych zasobów, by je rozpocząć, a pracownicy niekiedy pozostawali bez wypłaty przez rok albo więcej $^{59}$. Jak jest obecnie jasne, ani wygrana Syrizy, ani żadna pojedyncza nominacja na stanowisko (włącznie z tą Kouroumblisa) nie zakończyła działań na rzecz oszczędności ani w Grecji, ani nigdzie indziej na świecie. Jednak mianowanie polityka, choć w anglojęzycznych mediach nie wybrzmiało zbyt głośno, było symbolicznie ważne, biorąc pod uwagę grozę sytuacji wielu niepełnosprawnych w kraju. Mimo to, wkrótce po wyborach pojawił się szybki oraz przewidywalny sceptycyzm w środowiskach lewicowych (i, jak się okazało, słuszny) dotyczący ograniczeń ruchów masowych oraz ich możliwości działania w obliczu burżuazyjnej demokracji wyborczej (podobne obawy wyrażano w Chile, kiedy Vallejo i inny studenccy przywódcy zostali wybrani do parlamentu).

W tym samym czasie, na całym kontynencie, reakcja establishmentu na początkowe zwycięstwo Syrizy była nawet bardziej przewidywalna (i szybka). „Economist” - w głównym materiale z 31 stycznia 2015 roku - przyznał, że wprawdzie dług Grecji jest niemożliwy do zniesienia, ale twierdził zarazem (w ableistycznym języku łączącym „szaleństwo” ze wszystkim, co

H. Smith, I. Traynor Greek PM Alexis Tsiprac Unveils Cabinet of Mavericks and Visionaries, "Guardian" 27.01.2015, www.thequardian.com (dostęp: 27.10.2015). com (dostęp: 27.10.2015). 
sprzeciwia się powszechnemu poparciu dla polityki oszczędności), że konieczne jest ,zmuszenie Pana Tsiprasa do wrzucenia do kosza jego szalonego socjalizmu i trzymania się strukturalnych reform w zamian za umorzenie długów" ${ }^{\text {60 }}$ Posługując się jeszcze bardziej lekceważącym językiem (w zasadzie porównującym jakiekolwiek stanowisko, które byłoby przeciwko konsensusowi w sprawie cięć do perwersyjnych namiętności), artykuł sugerował, że „Pan Tsipras mógłby dać upust swoim lewackim chęciom przez sprzeciw wobec greckiej dobrze chronionej oligopoli i palącej korupcji", ale takie antyoszczędnościowe działania [jakie proponował wówczas Tsipras - przyp. tłum.] „zniweczyłyby cały grecki wysiłek nakierowany na konkurencyjność"61. Niemcy Angeli Merkel oraz ich sojusznicy, jak już sugerowałem, w żaden sposób nie dążyli do kompromisu w sprawie „reform strukturalnych".

Artykuł zamieszczony w „Economist” w styczniu 2015 roku jest jednak interesujący z punktu widzenia studiów nad niepełnosprawnością ze względu na swoją przewidywalność i jasno sygnalizowane stanowisko, zwłaszcza w relacji do - jak pokazał bieg czasu - niezdolności do wprowadzenia zmian przez Syrizę. Okładka magazynu, związana z głównym materiałem, przedstawia Wenus z Milo, a więc pozbawiony rąk posąg kobiety, na tle niebieskiego nieba. Zajmujący się niepełnosprawnością artyści i aktywiści od dawna zwracali uwagę, że ten symbol kobiecej urody jest - jak na ironię - znany nam tylko w niepełnosprawnej formie, choć ableistyczna historia sztuki i edukacja przysłaniają nam ten raczej dość prosty fakt. Mary Duffy jest współczesną performerką pozbawioną rąk, która w rzeczywistości wygląda jak Wenus z Milo i - w ramach swoich wystąpien - dekonstruuje tradycyjne, zachodnie postrzeganie piękna oraz odkrywa przeświadczenia oraz przemilczenia, na których się ono opiera ${ }^{62}$. Okładka „Economist” odtwarza brak prawej ręki, ale

60 Greece and the Euro's Future: Go Ahead, Angela, Make My Day, "Economist" 31.01.2015, www.economist.com (dostęp: 27.10.2015).

61 Tamże.

62 Lennard J. Davis w Nude Venuses, Medusa's Body, and Phantom Limbs: Disability and Visuality nie docenia - w analizie prac Duffy - argumentu ableistycznego wyparcia dotyczącego Wenus z Milo. O performansach Duffy pisze również Rosemarie Garland-Thomas. Por. L.J. Davis Nude Venuses, Medusa's Body, and Phantom Limbs: Disability and Visuality, w: The Body and Physical Difference: Discourses of Disability, ed. by D.T. Mitchell, S.L. Nyder, University of Michigan Press, Ann Arbor 1997, s. 63; oraz R. Garland-Thomson Dares to Stares: Disabled Women Performance Artists and the Dynamics of Staring, w: Bodies in Commotion: Disability and Performance, ed. by C. Sandahl, P. Auslander, University of Michigan Press, Ann Arbor 2005, s. 36, 37. 
zmienia wygląd lewej: Wenus z Milo trzyma w wyciągniętej dłoni pistolet skierowany mniej więcej w stronę, na którą pada spojrzenie posągu. „Dalej Angela, daj mi powód!" [Go Ahead, Angela, make my day] - mówi podpis umieszczony nad głową figury, a mniejszy napis w dolnym prawym rogu dodaje „Greckie wyzwanie dla Niemiec i strefy Euro”. Kaleki posąg reprezentuje więc cierpienie Grecji oraz wpływ, jaki wywiera nań polityka oszczędności. Choć dla „Economist” jest to niezamierzenie lub nieświadomie kaleka reprezentacja, to jest ona wciąż obecna na wierzchu okładki tak, jak niepełnosprawność znajduje się na powierzchni każdej polityki oszczędności, nawet wtedy, gdy się tego nie dostrzega. Co więcej, opór jest, w mocnym odczytaniu tego obrazu, przedstawiony jako opór kalek (i oczywiście nie ma powodu, by n i e czytać okładki w oderwaniu od intencji magazynu i neoliberalnego ukierunkowania głównego materiału). To bezbronne, okaleczone ciało reprezentuje tu wszystkie bezbronne ciała w Grecji i w gruncie rzeczy mówi z tej kalekiej perspektywy (z której całość społeczeństwa może być lepiej widzialna): dość już tego. Słowa użyte poniżej („dalej Angela, daj mi powód”) są oczywiście szeroko używane w kulturze popularnej, ale pewna ironia tkwi w fakcie, że były one po raz pierwszy wypowiedziane przez amerykańskiego aktora oraz republikańskiego polityka, Clinta Eastwooda, i wyrażały surowy, renegacki indywidualizm wczesnych lat neoliberalizmu (jak Brudny Harry w Nagłym zdarzeniu z 1983 roku). Tu w kontraście słowa te są przepisane przez obraz, który wprost, w wojowniczy sposób, przeciwstawia się głównym reprezentantom neoliberalizmu w Europie.

Reakcje na rzeczywistą politykę Syrizy zmieniały się w trakcie roku 2015 dość gwałtownie, tragicznie przechodząc od ostrożnego optymizmu przez rezygnację do ekstremalnego pesymizmu i nawet konsternacji. Tsipras i Varoufakis na początku wyrażali wolę podniesienia płacy minimalnej, ponownego zatrudnienia zwolnionych (zwłaszcza sprzątaczy, którzy zaangażowali się $\mathrm{w}$ antyoszczędnościowy aktywizm po utracie pracy), wstrzymania prywatyzacji publicznych zasobów i zbierania podatków od najlepiej sytuowanych. Planem było więc utrzymanie poparcia tych, którzy głosowali na partię. Choć politycy nie deklarowali wprost zalegania ze spłatami lub wyjścia ze strefy euro, dawali jasno do zrozumienia, że nie będą niwelować długu przez coraz mocniejsze cięcia.

Grecka rzeczywistość szybko okazała się bardziej skomplikowana niż plany i przypuszczenia, a Tsipras jest obecnie postrzegany głównie - na politycznej lewicy - jako osoba, która się poddała. 20 lutego 2015 roku, mniej niż miesiąc po wyborach, bez żadnego zewnętrznego wsparcia od innych 
krajów w strefie euro (i z poza niej), Syriza została zmuszona do wydłużenia istniejącej już umowy pożyczkowej. Umowa dotycząca wydłużenia uznawała cały istniejący dług oraz wszystkie zasady jego spłaty. Co ważne, w trakcie okresu przedłużenia, dług miał być spłacany pod stałym „nadzorem”, w gruncie rzeczy wskazującym, że troika będzie kontynuowała zarządzanie polityką oszczędności w Grecji. Jak twierdził Stathis Kouvelakis w czasopiśmie „Jacobin”, europejscy liderzy powinni „związać ręce i nogi rządowi Syrizy, by pokazać w praktyce, że żaden wynik wyborów oraz rozwiązania, jakie może przyjąć wyłoniony rząd, nie będą oznaczały zmiany polityki oszczędności, mieszczącej się w już istniejącej europejskiej strukturze"63. To, co można stwierdzić na poziomie strategii (w rozumieniu terminu de Certeau), nie jest szczególnie optymistyczne: strażnicy cięć zarówno w Grecji, jak i na kontynencie, są zdecydowanie silniejsi, zarówno w tworzeniu taktyk, jak i blokowaniu antyoszczędnościowych alternatyw. Jednak wybór Syrizy przynajmniej zaznaczył pęknięcie w rządowej akceptacji oszczędności. W momencie, kiedy skończyłem pisać Crip Times, pęknięcie to nie przerodziło się jednak w bardziej całościową strategię przeciwko oszczędnościom.

Późnym czerwcem 2015 roku, w obliczu trwałego braku wsparcia, a nawet oznak wrogości ze strony Merkel i Schäublego, Tsiprac zwołał referendum narodowe: Grecy mogli albo zaakceptować, albo odrzucić głębokie oszczędności, jakich żądała troika. Nowa umowa, łącząca pomoc Grecji z kolejnymi "reformami", została przedstawiona bez żadnych kompromisowych zmian dotyczących oszczędności. Tsipras przekazał ją wyborcom, ogłaszając referendum w chwili, która - jak wiele osób sugeruje - mogła mu przynieść międzynarodową wiarygodność w starciu z europejskimi liderami. OXI, greckie słowo oznaczające „nie”, zaczęło szybko krążyć po świecie, oznaczając poparcie dla odrzucenia proponowanego pakietu pomocowego, zawierającego konieczność oszczędności. 5 lipca 2015 roku ludność Grecji rzeczywiście zagłosowała - w przytłaczającej większości - przeciwko pakietowi. Varoufakis podał się do dymisji następnego dnia, nie dlatego, że nie zgadzał się z wynikami, które były szeroko i bardzo emocjonalnie utożsamiane z odrzuceniem oszczędności, ale z powodu presji, jakiej był poddawany przez europejskich liderów przez sześć miesięcy wcześniejszych negocjacji. Przed połową lipca Tsipras, mimo referendum i przy niedowierzaniu wielu obserwatorów, zdecydował się zgodzić na żądania. Osoba, która rozpoczęła

63 S. Kouvelakis The Alternative in Greece, "Jacobin Magazine" 24.02.2015, www.jacobinmag.com (dostęp: 27.10.2015). 
krucjatę przeciwko oszczędnościom, skończyła jako piewca idei „Nie ma alternatywy" dla oszczędności ${ }^{64}$. Choć popularność polityka szybko się zakończyła i Tsipras zwołał nowe wybory na wrzesień, Syriza została wybrana ponownie, tym razem zapewne z powodu rezygnacji części głosujących oraz pesymizmu dotyczącego możliwości osiągnięcia zmiany za pomocą procesu wyborczego.

Moim zamiarem w tym rozdziale jest jednak scharakteryzowanie różnych kalekich taktyk, przy równoczesnym uznaniu, że wskazują one (oraz globalna polityka oszczędności) na konieczność budowania szerszych strategii, nawet wtedy, kiedy takie strategie okazują się rozczarowujące praktycznie od momentu, w którym się pojawiają. Grecka tragedia, dotycząca Syrizy i Tsiprasa, pokazuje jasno, że nie jest możliwa wielka antyoszczędnościowa nadzieja i że to, co się stanie, jeśli Syriza utrzyma władzę, nie jest wcale pewne. Tutaj jestem jednak zainteresowany głównie sposobami, w jakie aktywiści organizują oraz podtrzymują społeczne placówki medyczne zarówno przed, jak i w trakcie rządów Tsiprasa. Renciści, emeryci i inni niepełnosprawni protestanci w Grecji zaangażowali się w różne formy aktywizmu. W rzeczywistości, większość taktyk, o których mówię w tej części, opiera się na tradycyjnych formach aktywizmu (na przykład marsze i protesty), ale równocześnie (jak rzeźba społeczna w Kalifornii, pragnienie niepełnosprawności w Chile, czy radykalna reartykulacja człowieczeństwa w Hiszpanii) daleko je przekracza. Społeczne centra medyczne w Grecji, jak sądzę, działają w podobnie wizjonerski sposób.

Tym, co interesuje mnie najbardziej w greckim aktywizmie, kształtującym te placówki, jest jego uporczywe przywiązanie do myślenia wraz z o ra z przeciw lub ponad państwu równocześnie. Po wielkich protestach w 2011 roku, otwarto ponad 40 społecznych centrów medycznych. Od kiedy obcięto dotację na służbę zdrowia o połowę ("Guardian” stwierdza, że „nawet pacjenci z ubezpieczeniem płacą więcej niż 70\% ceny za swoje leki"), kliniki używają leków i sprzętu z darów ${ }^{65}$. W samych Atenach więcej niż 30000 pacjentów

64 The Is No Alternative - albo TINA - jest podejściem - albo ideologią - które zyskało popularność wraz ze wzrostem poparcia dla thatcheryzmu w Wielkiej Brytanii (Margaret Thatcher używała tego sformułowania dla usprawiedliwienie neoliberalnych reform państwa i gospodarki). Hasłem tym od tamtego czasu powszechnie posługują się obrońcy neoliberalizmu i polityki oszczędności.

65 J. Henley Greece's Solidarity Movement: "It's a Whole Model - and It's Working", "Guardian" 23.01.2015, www.thequardian.com (dostęp: 29.10.2015). 
miesięcznie jest leczonych w 16 różnych społecznych centrach ${ }^{66}$. Placówki są częścią dużo większego ruchu, zarządzanego przez mieszkańców (podobne działania dotyczą, na przykład, dystrybucji jedzenia), a ruch ten jest kaleki przez swoje zaangażowanie w zbiorowe potrzeby ciał oraz ich słabości, a także opór wobec sposobów, na jakie polityka oszczędności bogaci się na najsłabszych. Przychodnie medyczne powstawały o d d oln i e, ale przynajmniej przez jakiś czas były również „zasilane przez Syrizę”, jak twierdzi Joanna Ramiro ${ }^{67}$. „Solidarity 4 All” [Solidarność dla wszystkich] było nazwą (dotowanej przez Syrizę) grupy-parasola, pracującej z aktywistami zapewniającymi opiekę medyczną i darmowe leki tym, dla których stały się one niedostępne w warunkach oszczędności.

Istnieje wiele powodów (zwłaszcza biorąc pod uwagę, jak neoliberalne państwo funkcjonowało, wyraźnie chroniąc interesy kapitału i działając z nim ręka w rękę), by odwrócić się od opartych na państwie rozwiązań dotyczących problemów wywołanych przez politykę oszczędności. Solidarność dla wszystkich nie jest, w sposób dość oczywisty, mottem działania j a ki e g o k olw i e k rzeczywiście istniejącego państwa w tych kalekich czasach. Teoria queer (szczególnie po zwrocie w kierunku globalizacji i materializmu) jest w tym ponurym kontekście - głęboko podejrzana, bardziej jeszcze niż studia nad niepełnosprawnością, z powodu przyjęcia oraz wcielenia tego, co Margot Canaday określiła jako „normalne państwo"68. Niektórzy teoretycy - być może najważniejszy byłby tu J. Jack Halberstam - zachęcają nas, by przestać kierować nasze żądania do państwa i prosić, by w ich toku jakoś nas „rozpoznało"69. Generalnie, żądanie rozpoznania wiązało się od lat 9o. ze światową walką o prawo do małżeństwa. Zważywszy fakt, jak kwestia ta odwracała uwagę od szerszych problemów, związanych ze sprawiedliwością społeczną, krytyka centralności tego postulatu w najważniejszych ruchach LGBT pozostaje paląca, a queerowa praca, kwestionująca chęć bycia rozpoznanym przez państwo, jest ważna i obiecująca.

Droga ta przedstawia się jednak - kiedy kulejemy w kryzysie - dość zagadkowo.Tak naprawdę istnieje wiele sposobów, na które można stosunkowo

66 Tamże.

67 J. Ramiro Wish We Were Here: A Melancholy Postcard, "Salvage” 1.07.2015, S. 102.

68 M. Canady The Straight State: Sexuality and Citizenship in Twentieth-Century America, Princeton University Press, Princeton 2009, s. 1.

69 J.J. Halberstam Gaga Feminism: Sex, Gender, and the End of Normal, Beacon Press, Boston 2012, s. $95-130$. 
łatwo odmówić państwowego rozpoznania w odniesieniu do gejowskich małżeństw. Jednak nie jest to już takie proste, kiedy rozmawiamy o respiratorach, wózkach inwalidzkich i lekach, utrzymujących ludzi przy życiu. Emeryci, którzy utracili w Grecji dostęp do niezbędnych środków, protestowali w tym krytycznym momencie - co wydaje się zupełnie usprawiedliwione - przez tłuczenie w garnki i patelnie oraz wysuwanie gniewnych oskarżeń wycelowanych dokładnie w krnąbrne państwo ${ }^{70}$. Jeden z transparentów z protestów w roku 2011 stwierdzał: „Dali 200 miliardów bankierom, ale oszczędzają na lekach, leczeniu i pomocy dla niepełnosprawnych". W tym zdaniu widać wyraźne odrzucenie państwa („patrz, co zrobili” - zdaje się stwierdzać), ale jest w nim również niemożliwa do przeoczenia, pilna potrzeba policzenia się z państwem, skoro mowa jest o świadczeniach, które są potrzebne natychmiast. Niepełnosprawni aktywiści byli również - co ważne - nie tak redukcyjnie nastawieni do państwa, jak radykalni queerowie w USA, Kanadzie i Wielkiej Brytanii, negujący małżeństwo oraz towarzyszące mu prawne rozpoznanie. Kaleka strategia, przyjmowana przez społeczne placówki medyczne, tworzy podwójny ruch, budujący anarchistyczne formy lokalnej opieki medycznej przy równoczesnym uznaniu potrzeby szerszych, państwowych taktyk i ponadpaństwowego wysiłku nakierowanego na zakończenie polityki oszczędności. Syrizie - przynajmniej w roku 2015 - nie udało się wykształcić takich trwałych strategii, niemniej porażka tej partii w podtrzymywaniu solidarność ze wszystkimi nie wstrzymała procesu tworzenia kreatywnych i zbiorowych, oddolnych form oporu.

\section{Taktyka 6. Przejęcie i teatralizacja}

Powrócę teraz do Wielkiej Brytanii, przestrzeni oszczędności znajdującej się w centrum moich badań w książce Crip Times, by omówić ostatnią z kalekich taktyk, którą David Halperin określał jako queerową: przejęcie i teatralizację $^{71}$. Zdaniem badacza, queerowe przejęcie i teatralizacja dominujących

70 Nie twierdzę, że łatwo jest protestować przeciwko sposobom, na które kwestia prawa do małżeństwa oraz do służby wojskowej została przejęta przez mainstream, liberalne ruchy gejowskie w USA albo na świecie. Sugeruję natomiast, że odmowa "rozpoznania” w kontekście LGBT często wynika z zasadniczej oraz queerowej dysidentyfikacji z potrzebą rozpoznania czyjejś tożsamości przez państwo. Chęć „rozpoznania przez państwo”, czasem wyrażane przez ludzi z niepełnosprawnościami, nie jest koniecznie (ani zawsze) związane z prostą oceną tożsamości i tym samym jest innym rodzajem żądania, który trudno odrzucić w całości. 
dyskursów, wytworzonych wprost przez „homofobiczny mechanizm”, pozwala na opór. "Jakie możliwości dla dyskursywnych kontrpraktyk tworzy dyskursywne kształtowanie seksualności?"72. Halperin jako przykład odpowiedzi na to pytanie podaje reakcję gazety „Bay Times” na czerwcowy numer „Newsweeka” z roku 1993, który przedstawiał dwie uśmiechnięte białe lesbijki, wraz z nagłówkiem „Lesbians: Coming out Strong, What Are the Limits of Tolerance?" [Lesbijki: mocne wyjście. Jakie są granice tolerancji?]. Kilka tygodni później „Bay Times” (gazeta LGBT z San Francisco) opublikowała okładkę fikcyjnego czasopisma zatytułowanego „Dyweweek” z obejmującą się parą: białym mężczyzną i kobietą oraz podpisem „Heteroseksualni: jakie są granice tolerancji?"73. Przejęcie i odwrócenie, jakie zastosował „Dykeweeek”, zawierało „słownik”, wyjaśniający takie terminy, jak: „żona: tradycyjnie «żeński» partner (w heteroseksualnym związku), odpowiedzialny za prace domowe i opiekę nad dziećmi"74.

„Okaleczanie",jako dyskursywna kontrpraktyka, było również w kalekich czasach szeroko oraz ostentacyjnie teatralne. Zgodnie z tezą badaczki niepełnosprawności i performatyki, Carrie Sandahl: „zarówno queerowanie, jak i okaleczanie odsłaniają arbitralne podziały między normalnym i ułomnym oraz... obie [taktyki - przyp. tłum.] rozbrajają z pomocą szelmowskiego humoru, korzystającego też z kampu"75. We wrześniu 2012 roku, po olimpiadzie w Londynie, brytyjska artystka performatywna Crip2Night otwarcie przejęła i steatralizowała - w dosłownie czarno-białych barwach - spektakl paraolimpiady przez krytyczne zestawienie (za pomocą słowa cripocracy [kalekopokryzja]) dwóch komunikatów: „120 medali, 304 sportowców, nieskończona duma narodowa” oraz „Renty inwalidzkie zmniejszono o 20\%, pół miliona osób straci świadczenia" i pytania „Narodowa duma?”. Po lewej, kolorowej stronie fotografii, brytyjska flaga pokrywa każdy cal Crip2Night: kobieta ma na sobie kapelusz i kolorowe okulary przeciwsłoneczne z tym motywem, papierowe talerze z tym samym wzorem ozdabiają koła jej wózka, a z boku i z tyłu powiewają dwie flagi (z napisem „Zespół Wielkiej Brytanii” dumnie umieszczonym na jednej). Po prawej, czarno-białej stronie zdjęcia,

72 Tamże, s. 48.

73 Tamże, s. 50.

Cytat za: tamże, s. 51.

C. Sandhal Queering the Crip or Cripping the Queer? Intersections of Queer and Crip Identities in Solo Autobiographical Performance, "GLQ: A Journal of Lesbian and Gay Identities" 2003, vol. 9, no. 1-2, s. 37. 
Crip2Night jest ubrana na czarno i ma na sobie ciemne okulary, a flagę oraz wózek zakrywają czarne worki na śmieci. Projekt „This Is What Disability Looks Like" dosłownie wchłonął i rozpropagował fotografię Crip2Night.

To oczywiście tylko jeden obraz albo performans, i to nie ten, który zyskał najszerszą popularność. Może być on jednak uznany za reprezentatywny dla dyskursywnych kontrpraktyk, żywych w Wielkiej Brytanii, w której artyści, aktywiści i inne zaangażowane osoby przejmowały, zajmowały, teatralizowały i przepisywały zasady ekstrawaganckiego odrzucenia, używanego do ich dyskredytowania, jako nie tylko (w oczywisty sposób) kalekich, ale również złamanych, symulujących, wyłudzających zasiłki, a nawet (w jednej dobrze znanej sprawie) określanych jako szumowiny. Kaliya Franklin, blogująca jako Bendy Girl oraz Benefit-Scrounging Scum, w początkach koalicji [Partii Konserwatywnej z Liberalnymi Demokratami - przyp. tłum.] stworzyła fotografię, której udało się uzyskać szerszą rozpoznawalność, niż zdjęciu Crip2Night. Obraz powstał w 2011 roku, kiedy pierwsza ustawa rządu koalicyjnego - na temat reformy systemu opieki społecznej - była w parlamencie. Zdjęcie zatytułowane Left Out in the Cold [Pozostawieni na lodzie] zostało stworzone dla kampanii „Broken of the Britain” [Złamani Wielkiej Brytanii]. Jest to nagi autoportret na opustoszałej plaży, zrobiony w zimny styczniowy dzień, w tracie przypływu, w Hoylake na zachód od Liverpoolu. Kiedy poruszaliśmy się - piechotą i na wózku - wzdłuż wybrzeża w ciepły dzień w lipcu 2014 roku, Franklin szybko dała mi do zrozumienia, że w czasie pracy nad zdjęciem na piasku był śnieg, a ona (i fotograf) byli wcześniej ubrani w kilka warstw odzieży. Obraz przedstawia pusty wózek na plaży; nie elektryczny, jakiego Franklin normalnie używa, ale skromniejszą, szpitalną wersję (która mogłaby być refundowana przez brytyjską służbę zdrowia). Franklin leży obok niego, $\mathrm{z}$ ramionami wyciągniętymi do przodu, być może w kierunku wózka, z twarzą i wzrokiem skierowanym prawie zupełnie w dół, na piasek.

"Osoby chore i niepełnosprawne są często pozbawione głosu w społeczeństwie" mówi artystka o fotografii, która - jak ma nadzieję - prowokuje do refleksji ${ }^{76}$. Ten teatralny obraz (i performance) interesuje mnie z wielu powodów, także dlatego, że wózek po raz kolejny (jak w przypadku huelgistas de hambre) oznacza "nie-sprawność” ale równocześnie wskazuje na inne niepełnosprawności i ograniczenia, nie tak łatwo widzialne. W istocie, zdjęcie Franklin pracuje wraz z oraz przeciw temu, co Kelly Fritsch określa jako

76 Cyt. za: Left Out in the Cold - press release, thebrokenofbritain.blogspot.com.br (dostęp: 29.05.2017). 
„neoliberalną cyrkulację afektów”, która zazwyczaj utożsamiania „niepełnosprawność z wózkiem inwalidzkim"77. Tymczasem w Left Out in the Cold wózek wspaniale reprezentuje zarówno to, czym jest, jak i czym nie jest. Franklin używa go do określenia i utożsamienia się z wszystkimi innymi [niepełnosprawnymi - przyp. tłum.], poniżanymi jako wyłudzające świadczenia szumowiny, a także z osobami cierpiącymi na choroby umysłowe oraz „niewidzialne niepełnosprawności" (wśród których są - by ponownie odwołać się do kampanii organizującej masowe protesty i marsze dotyczące cięć - najbardziej dotknięci przez oszczędności w Wielkiej Brytanii). Najcięższe testowe działania systemu Ato ${ }^{78}$ były często wycelowane nie w tych z najbardziej rozpoznawalnymi (lub reprezentatywnymi) niepełnosprawnościami, lecz tych, których ograniczenia manifestują się inaczej lub nie wprost. Osoby autystyczne, z przewlekłymi chorobami lub trudnościami w uczeniu się mogą bardzo potrzebować świadczeń i pomocy, choć ich problemy będą się różnić oraz zmieniać z dnia na dzień. Jednego dnia Atos (albo teraz Maximus) szybko ewaluuje status wielu osób i są one określane jako „zdolne do pracy” (oraz pozbawianie wielu świadczeń) na podstawie tego, jak ich niepełnosprawność wygląda w danym momencie. Takie osoby są pozostawiane na lodzie i nikną w pewien sposób, a performans Franklin pokazuje aktywną, celową nieobecność: znikanie zaplanowane przez architektów polityki oszczędności. Kiedy Cameron w swojej mowie wyborczej, o której wspominałem we wstępie do Crip Times, odwoływał się do „złamanej Brytanii", zamierzał zwrócić uwagę na osobiste, indywidulane porażki. Oczywiście nie mówił wprost o szumowinach, kiedy sam skazywał tysiące ludzi na upadek i ekstrawagancki wstręt oraz odrzucenie, ale jest jasne, że wiele osób tak właśnie odbierało jego słowa od roku 2010. Kampania „Broken of Britain” oraz uczestnicząca w niej Franklin przejęły i steatralizowały poniżającą retorykę Camerona w interesie zbiorowego oporu.

Kiedy pytałem Franklin o użycie najbardziej odstręczającego języka w jej blogowaniu i cyberaktywizmie (jako Benefit-Scrouning Scum), odpowiedziała, że było to świadome przejęcie pojęć używanych do deprecjonowania (albo, by użyć pojęć Badiou: do zmuszania do nieistnienia) najmocniej marginalizowanych grup. Inspiracją dla tej taktyki było dla niej doświadczenie

77 K. Fritsch The Neoliberal Circulation of Affects: Happiness, Accessibility and the Capacitation of Disability as Wheelchair, "Health, Culture and Society" 2013, vol. 5, no. 1, s. 3.

78 Jest to platforma cyfrowa używana między innymi w Wielkiej Brytanii do obsługi systemu opieki społecznej i zdrowotnej [przyp. tłum.]. 
życia w USA we wspólnotach (m.in. Afroamerykanów i LGBT), które mają długą tradycję przepisywania znaczeń w języku wcześniej używanym do ich poniżania. Left Out in the Cold i inne taktyki przejmowania wydają się bardziej „pornograficzne” niż strategie, które wcześniej analizowałem. Trudno zaprzeczyć, że ta piękna i przejmująca naga fotografia jest zaprojektowana, by wywoływać głód lub pożądanie, których związki z obrazami otwarcie pornograficznymi są złożone, lecz realne. Nie jest jednak utowarowiona i nie generuje prostej przyjemności lub inspiracji, jaką daje porno. Zamiast tego tworzy queerowy, wieloaspektowy głód lub pożądanie, skierowane na - by odwołać się do uwag Floyda na temat potencjału pornograficznego istnienia - „rozwój spektrum [kalekich - wtrącenie R. McRuer] queerowych formacji"79. Skoro tożsamość Franklin jako pisarki i aktywistki zrodziła się w kontakcie ze wspólnotami Afroamerykanów i LGBT, możemy powiedzieć, że omawiany performans reprezentuje tęsknotę za tym, co Robin D.G. Kelley określił jako "marzenie o wolności”80. Praca myśli LQBT i feministycznej „zachęca nas do konstruowania polityki zakorzenionej w pożądaniu", jak zauważa Kelley, kiedy opisuje ją w odniesieniu do radykalnej czarnej wyobraźni w XX wieku. Taka praca „kwestionuje, co jest «normalne» i pokazuje nam jak państwo oraz oficjalna kultura kształtują nasze zachowania"81. Kelly nie mówi wprost o niepełnosprawności, kiedy chwali tę politykę zakorzenioną w pożądaniu, podającą w wątpliwość, co jest normalne, podobnie jak Scott nie mówi na temat niepełnosprawności, analizując sposoby, na które tkwimy w zranieniu i ekstrawaganckim wstręcie. Zarówno wybierany przez Kelleyego oraz Scotta język, jak i transatlantycka, ucieleśniona solidarność z innymi marginalizowanymi grupami, której Franklin zawdzięcza model swojej pracy, sugerują jednak, że marzenia o wolności są również niepełnosprawne, tak, jak zawsze będą queerowe, feministyczne i czarne.

Left Out in the Cold było szczególnie ważne w roku 2011, jako zjadliwy komentarz do głosowanego w Parlamencie prawa. Jednak dla mnie fotografia ta stała się również dobrą reprezentacją potrzeby tworzenia identyfikacji oraz koalicji między grupami w Wielkiej Brytanii w dobie rządów Camerona. Choć to zdjęcie nie ma bezpośredniego związku z obrazem, który zyskał międzynarodową rozpoznawalność trzy lata później, to doskonale zapowiada

K. Floyd The Reification of Desire, s. 203.

80

R.D.G. Kelley Freedom Dreams: The Black Radical Imagination, Beacon Press, Boston 2002, s. 6.

81 Tamże. 
fotografię z września 2015 toku, przedstawiającą Alana Kurdiego. Trzyletni syryjski chłopiec utonął po tym, jak na Morzu Śródziemnym wywróciła się łódź, na której płynął wraz z krewnymi. Na zdjęciu widać jego pozbawione życia ciało, leżące na tureckiej plaży. Rodzina Kurdiego chciała się dostać do krewnych w Kanadzie i nie planowała nawet przejazdu przez Wielką Brytanię. Mimo to, tacy uchodźcy byli wyjątkowo atakowani w dominującym brytyjskim dyskursie, podobnie jak ludzie niepełnosprawni oraz niechciani wyłudzacze świadczeń. Dyskurs antyimigracyjny zyskał na sile w miesiącach poprzedzających głosowanie nad Brexitem i wielu emigrantów zostało dosłownie zostawionych na lodzie przez politykę oszczędności, wprowadzoną w czasie rządów Camerona. Po referendum, w mowie, która była powszechnie interpretowana jako konsolidująca dyskurs nacjonalistyczny, Theresa May niesławnie stwierdziła: „Kiedy wierzycie, że jesteście obywatelami świata, nigdzie nie jesteście obywatelami" ${ }^{\prime 2}$. W tak antyimigranckiej i ableistycznej kulturze nie jest trudno odczytać Left Out in the Cold anachronicznie, za pomocą tragicznego, późniejszego zdjęcia z roku 2015. I ważne jest, byśmy tak właśnie je interpretowali, by wspierać budowanie krzyżujących się tożsamości, postulowanych przez pisarstwo oraz fotografie Franklin.

Podsumuję ten rozdział cytatem z Lenina, który prawdopodobnie zostanie przekręcony lub okaleczony przez zmianę kontekstu: chociaż Lenin jest na wiele sposobów głównym architektem zarówno aktywnego oporu, jak i strategii w rozumieniu de Certeau, to nie zajmował się (kalekimi) taktykami oraz ekstrawaganckim wstrętem, które ja tu analizowałem, by odnaleźć sposób myślenia, sytuujący się ponad wywłaszczaniem zrodzonym z globalnej polityki oszczędności. Crip Times nie jest więc tekstem leninowskim. Niemniej, Lenin pisze: „kto oczekuje «czystej» rewolucji socjalnej, ten n ig dy sięjej nie doczeka. Ten jest rewolucjonistą tylko w słowach, człowiekiem nie rozumiejącym rzeczywistej rewolucji"83 (wyróżnienie oryginalne). Lenin stwierdza potem, że rewolucja w Europie "nie może być niczym innym, jak wybuchem masowejwalki wszystkich i wszelakich uciśnionych i niezad o w o l o ny c h. Części drobnomieszczaństwa i zacofanych robotników będą w niej nieuchronnie brały udział - bez takiego udziału nie jest możliwa walka

82 T. May, cyt. za: M. Bearak Theresa May Criticized the Term "Citizen of the World". But Half the World Identifies That Way, "Washington Post" 5.10.2016, www.washingtonpost.com (dostęp: 21.12.2016).

83 W. Lenin Powstanie irlandzkie w roku 1916, w: Dzieła wybrane w dwunastu tomach, t. 5, Wydawnictwo Literatury w Językach Obcych, Moskwa 1940, s. 330. 
masowa, nie jest możliwa żadna rewolucja - i równie nieuchronnie będą one wnosić do ruchu swoje przesądy, swoje reakcyjne fantazje, swoje braki i błędy" ${ }^{84}$ (wyróżnienie - R. McRuer). Moje przepisywanie Lenina jest zapewne samooczywiste $\mathrm{w}$ tym sensie, że choć w ogromnym stopniu polegam na wartościach, które mogą być postrzegane przez i w relacji do „słabości”, to dosłownie ni e widzę „reakcyjnych fantazji” w migawkach z globalnego, kalekiego aktywizmu, które pokazywałem czytelnikom w tym rozdziale (jak również nie dostrzegam wyraźnych przedstawicieli „drobnomieszczaństwa” albo „zacofanych robotników”). Jednak w Crip Times afirmuję i tropię rewolucję wraz z oraz ponad tradycyjnie zmobilizowaną klasą pracującą, rewolucję w pewien sposób ek sp a n sy w n i e złożoną z wyłudzaczy, szumowin, złamanych oraz „wszystkich i wszelakich uciśnionych i niezadowolonych". Jak już wskazywałem - razem z wieloma badaczami studiów nad niepełnosprawnością - uwielbiamy powtarzać tezę, że każdy będzie niepełnosprawny, jeśli będzie żył wystarczająco długo ${ }^{85}$. Jednak, jak pokażę w dwóch ostatnich rozdziałach tej książki, również bardziej spekulatywne tezy mogą być przydatne dla myślenia o oporze w naszych czasach, szczególnie w odniesieniu do światowej polityki oszczędności. Ekscesywny, kaleki opór, który analizowałem w tym rozdziale, wskazuje być może na dopiero powstający i ledwo dostrzegalny truizm, że każda rewolucja stanie się kaleka, jeśli będzie trwała wystarczająco długo.

Przełożyła Justyna Tabaszewska

\footnotetext{
84 Tamże.

85 R. McRuer Crip Theory: Cultural Signs of Queerness and Disability, NYU Press, New York 2006, S. 197-198.
} 


\section{Abstract}

\section{Robert McRuer}

DEPARTMENT OF ENGLISH, COLUMBIAN COLLEGE OF ARTS \& SCIENCES, THE GEORGE WASHINGTON UNIVERSITY

Crip Resistance

In this chapter from the book Crip Times: Disability, Globalization, and Resistance (New York: New York University Press, 2018), McRuer examines practices of crip resistance, both from a theoretical perspective (conceptualisations of resistance in queer theory and disability studies), and in a practical sense (analysing crip strategies of resistance developed by the disability community and by activists in Greece, the US, UK, Spain and Chile).

\section{Keywords}

disability, queer, resistance, crip 